\title{
Evaluation of the new UKCA climate-composition model - Part 1: The stratosphere
}

\author{
O. Morgenstern ${ }^{1, *}$, P. Braesicke ${ }^{1}$, F. M. O'Connor ${ }^{2}$, A. C. Bushell ${ }^{3}$, C. E. Johnson ${ }^{2}$, S. M. Osprey ${ }^{4}$, and J. A. Pyle \\ ${ }^{1}$ NCAS-Climate-Chemistry, Chemistry Department, Cambridge University, UK \\ ${ }^{2}$ Met Office Hadley Centre, Exeter, UK \\ ${ }^{3}$ Met Office, Exeter, UK \\ ${ }^{4}$ Sub-Department of Atmospheric, Oceanic and Planetary Physics, University of Oxford, UK \\ *now at: National Institute of Water and Atmospheric Research, Lauder, New Zealand
}

Received: 17 November 2008 - Published in Geosci. Model Dev. Discuss.: 12 December 2008

Revised: 26 February 2009 - Accepted: 13 March 2009 - Published: 20 March 2009

\begin{abstract}
The UK Chemistry and Aerosols (UKCA) model is a new aerosol-chemistry model coupled to the Met Office Unified Model capable of simulating composition and climate from the troposphere to the mesosphere. Here we introduce the model and assess its performance with a particular focus on the stratosphere. A 20-year perpetual year-2000 simulation forms the basis of our analysis. We assess basic and derived dynamical and chemical model fields and compare to ERA-40 reanalyses and satellite climatologies. Polar temperatures and the lifetime of the southern polar vortex are well captured, indicating that the model is suitable for assessing the ozone hole. Ozone and long-lived tracers compare favourably to observations. Chemical-dynamical coupling, as evidenced by the anticorrelation between winterspring northern polar ozone columns and the strength of the polar jet, is also well captured. Remaining problems relate to a warm bias at the tropical tropopause, slow ascent in the tropical pipe with implications for the lifetimes of long-lived species, and a general overestimation of ozone columns in middle and high latitudes.
\end{abstract}

\section{Introduction}

Coupled chemistry-climate models (CCMs) are needed to study the multiple links between ozone, greenhouse gases (GHGs), including ozone precursors and ozone-depleting substances (ODSs), and the dynamical components of the climate system. Such models are used to study, e.g., the response of the ozone layer to climate change and conversely

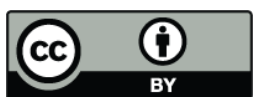

Correspondence to: O. Morgenstern (o.morgenstern@niwa.co.nz) the active role of ozone in a changing climate (WMO, 2007; IPCC, 2007). Presently there are only a few CCMs available that cover both tropospheric and stratospheric ozone chemistry (e.g., Jöckel et al., 2006; Garcia et al., 2007). However, the links between the two regions are increasingly recognized. For example, it is clear that future changes in stratospheric ozone will significantly impact tropospheric composition (Zeng and Pyle, 2003) and surface climate (Morgenstern et al., 2008). Such coupled models will become increasingly widespread. Ozone recovery will likely be associated with decreasing actinic fluxes in the lower stratosphere, leading to increasing atmospheric lifetimes, and possibly increased abundances, of some long-lived greenhouse gases (GHGs). The Antarctic ozone hole has been associated with substantial climate change in middle to high southern latitudes (Thompson and Solomon, 2002); this development is likely to reverse as the ozone recovers. However, the picture is complicated by simultaneous accumulation of GHGs in the atmosphere, leading to stratospheric cooling, increased abundance of polar stratospheric clouds (PSCs) and enhanced chlorine activation, delaying ozone recovery during polar spring. There is also a suggestion, recently challenged, that climate change may lead to a faster overturning of the stratosphere (Waugh, 2009, and references therein). In addition, volcanic eruptions can substantially perturb ozone chemistry and the climate system. Furthering our understanding of all of these processes usually requires coupled climate-chemistry modelling.

Given the increasing importance of CCMs, the MetOffice (the UK climate and weather forecasting agency) and the National Centre for Atmospheric Science (NCAS) have joined forces to develop a next-generation aerosol-chemistry model, the UK Chemistry and Aerosols (UKCA) model

Published by Copernicus Publications on behalf of the European Geosciences Union. 
(http://www.ukca.ac.uk), which will form an integral part of the Met Office Unified Model (MetUM). When completed, this model will link aerosol and gas phase chemistry in a troposphere-stratosphere environment. The new model will be used in upcoming World Meteorological Organization (WMO) ozone and Intergovernmental Panel on Climate Change (IPCC) assessments and will form part of the new QUEST Earth System model (http://quest.bris.ac.uk). The main focus of the present paper is to document the setup of a stratospheric-chemistry version of UKCA and assess its chemical and dynamical performance versus available observations and climatologies. The results presented in this paper derive from an integration of the UKCA model performed as part of our contribution to the Stratospheric Processes And their Role in Climate (SPARC) ChemistryClimate Model Validation (CCMVal) activity (http://www. atmosp.physics.utoronto.ca/SPARC/index.html; http://www. pa.op.dlr.de/CCMVal/). In the subsequent sections we present a model description, assessments of climate, chemistry, and chemical-dynamical coupling, and a synthesis of the model performance. The performance of UKCA with respect to tropospheric chemistry and aerosols will be the subject of parts 2 and 3 of this publication.

\section{Model description}

The whole-atmosphere and stratospheric versions of UKCA, called here Strat-UKCA, are based on a middle-atmosphere version of the MetOffice Unified Model (MetUM) with 60 levels in the vertical, a top lid at $84 \mathrm{~km}$, and a horizontal resolution of $3.75^{\circ} \times 2.5^{\circ}$. Morgenstern et al. (2008) use the model to study the impact on climate of ozone loss avoided by the Montreal Protocol; the version used here is almost identical to theirs. The dynamical core of the model is described by Davies et al. (2005). Due to the model's nonhydrostatic formulation the vertical coordinate system in the model is hybrid-height, unlike most climate models. Advection in the model is semi-Lagrangian (Priestley, 1993). Gravity wave drag comprises an orographic (Webster et al., 2003) and a parameterized spectral component (Scaife et al., 2002); the latter addresses momentum transport from the troposphere to the middle atmosphere. Radiation follows Edwards and Slingo (1996) with 9 bands in the long- and 6 in the shortwave part of the spectrum. In the version considered here the model is run in an atmosphere-only mode forced with prescribed sea surface temperatures (SSTs) and sea ice. Here, perpetual year-2000 SSTs and sea ice from the HadISST climatology (Rayner et al., 2003) are used.

For Strat-UKCA we have added to the model a comprehensive description of stratospheric chemistry, including chlorine and bromine chemistry and heterogeneous processes on polar stratospheric clouds (PSCs) and liquid sulphate aerosols (based on Chipperfield and Pyle, 1998). Note that a simplified tropospheric chemistry is also included. The
Table 1. Species predicted by Strat-UKCA. Highlighted in bold are species that feed into the radiation, underlined are species that experience dry deposition, and italicised are species that are wetdeposited. Other radiatively active species comprise $\mathrm{O}_{2}, \mathrm{CO}_{2}$, and $\mathrm{H}_{2} \mathrm{O}$.

$$
\begin{aligned}
& \mathrm{O}\left({ }^{1} \mathrm{D}\right), \mathrm{O}\left({ }^{3} \mathrm{P}\right), \underline{\mathbf{O}_{3}}, \\
& \mathrm{H}, \mathrm{OH}, \mathrm{HO}_{2}, \mathrm{H}_{2} \mathrm{O}_{2}, \\
& \mathrm{~N}, \underline{\mathrm{NO}}, \mathrm{NO}_{2}, \frac{\mathrm{NO}_{3}}{\mathrm{~N}_{2} \mathrm{O}_{5}}, \frac{\mathrm{HONO}}{2}, \overline{\mathrm{HO}_{2} \mathrm{NO}_{2}}, \mathbf{N}_{2} \mathbf{O}, \\
& \mathrm{CH}_{4}, \mathrm{CH}_{3} \mathrm{O}_{2}, \frac{\mathrm{CH}_{3} \mathrm{OOH}}{\mathrm{HCHO}}, \overline{\mathrm{CO}}, \\
& \mathrm{Cl}, \mathrm{ClO}, \mathrm{OClO}, \mathrm{Cl}_{2} \mathrm{O}_{2}, \mathrm{HCl}, \mathrm{HOCl}, \mathrm{ClONO}_{2}, \mathrm{CFCl}_{3}, \mathbf{C F}_{2} \mathbf{C l}_{2}, \\
& \mathrm{Br}, \mathrm{BrO}, \mathrm{BrCl}, \mathrm{HBr}, \mathrm{HOBr}, \mathrm{BrONO}_{2}, \mathrm{CH}_{3} \mathrm{Br}
\end{aligned}
$$

chemistry is embedded in a flexible way using the ASAD framework (Carver et al., 1997), built around a symbolic non-families sparse-matrix Newton-Raphson solver (derived from Wild and Prather, 2000). Table 1 summarizes the species predicted by the chemistry part of Strat-UKCA. $\mathrm{O}_{2}$, $\mathrm{N}_{2}, \mathrm{H}_{2}$, and $\mathrm{CO}_{2}$ are not predicted by the chemistry and are assumed uniform. Chemical water production or loss is deliberately ignored in the chemistry and instead a parameterization for stratospheric water vapour production is used based on Untch et al. (1998) which assumes a uniform distribution of equivalent water $\mathrm{H}_{2} \mathrm{O}+2 \mathrm{CH}_{4}=6.03$ ppmv. We also set water vapour equal to $3.5 \mathrm{ppmv}$ in the tropical lower stratosphere (between $30^{\circ} \mathrm{S}$ and $30^{\circ} \mathrm{N}$ and between 18 and $23 \mathrm{~km}$ ). This procedure is followed because this model version has a warm bias above the tropical tropopause (see below). Chemical reactions and their respective references are summarized in Tables 2-5. Bimolecular and termolecular reaction rates are amalgamated from Atkinson et al. (2000) and Sander et al. (2003), as indicated in Tables 2 and 3. Photolysis rates are defined following the procedure outlined below (Table 4): Where available, photolysis in the troposphere (below $300 \mathrm{hPa}$ ) follows tabulated rates calculated off-line in the Cambridge 2-D model (updated from Harwood and Pyle, 1975), as also used by the Cambridge TOMCAT (Law et al., 1998) and UM_UCAM (Zeng and Pyle, 2003) models. In the stratosphere (above $200 \mathrm{hPa}$ ), and in the troposphere for species not included in TOMCAT, a second set of offline precalculated rates updated from Lary and Pyle (1991), as used by Chipperfield (1999), is used. The stratospheric photolysis rates respond to changes in the overhead ozone column. In the intermediate region (between 200 and 300 $\mathrm{hPa}$ ) a linear transition is made between the two rates. Online photolysis rates using the FAST-J2 scheme (Bian and Prather, 2002) are available in the model but are not used here due to the omission of scattering at short wavelengths which would be important for polar ozone chemistry; this has been corrected in the more recent FAST-JX scheme (Neu et al., 2007). We plan to incorporate FAST-JX in future versions of UKCA. Some photolysis reactions with branching $\left(\mathrm{ClONO}_{2}, \mathrm{BrONO}_{2}, \mathrm{HO}_{2} \mathrm{NO}_{2}\right)$ have been updated following Sander et al. (2003). Heterogeneous reaction rates follow 
Table 2. Bimolecular reactions in Strat-UKCA. A=Atkinson et al. (2003). B=Sander et al. (2002).

\begin{tabular}{|c|c|c|c|c|}
\hline 1 & $\mathrm{Br}+\mathrm{Cl}_{2} \mathrm{O}_{2}$ & $\rightarrow$ & $\mathrm{BrCl}+\mathrm{Cl}+\mathrm{O}_{2}$ & A \\
\hline 2 & $\mathrm{Br}+\mathrm{O}_{3}$ & $\rightarrow$ & $\mathrm{BrO}+\mathrm{O}_{2}$ & A \\
\hline 3 & $\mathrm{Br}+\mathrm{OClO}$ & $\rightarrow$ & $\mathrm{BrO}+\mathrm{ClO}$ & A \\
\hline 4 & $\mathrm{Br}+\mathrm{HCHO}$ & $\rightarrow$ & $\mathrm{HBr}+\mathrm{CO}+\mathrm{HO}_{2}$ & B \\
\hline 5 & $\mathrm{Br}+\mathrm{HO}_{2}$ & $\rightarrow$ & $\mathrm{HBr}+\mathrm{O}_{2}$ & A \\
\hline 6 & $2 \mathrm{BrO}$ & $\rightarrow$ & $2 \mathrm{Br}+\mathrm{O}_{2}$ & B \\
\hline 7 & $\mathrm{BrO}+\mathrm{ClO}$ & $\rightarrow$ & $\mathrm{Br}+\mathrm{OClO}$ & A \\
\hline 8 & $\mathrm{BrO}+\mathrm{ClO}$ & $\rightarrow$ & $\mathrm{Br}+\mathrm{Cl}+\mathrm{O}_{2}$ & A \\
\hline 9 & $\mathrm{BrO}+\mathrm{ClO}$ & $\rightarrow$ & $\mathrm{BrCl}+\mathrm{O}_{2}$ & A \\
\hline 10 & $\mathrm{BrO}+\mathrm{NO}$ & $\rightarrow$ & $\mathrm{Br}+\mathrm{NO}_{2}$ & A \\
\hline 11 & $\mathrm{BrO}+\mathrm{HO}_{2}$ & $\rightarrow$ & $0.98\left(\mathrm{HOBr}+\mathrm{O}_{2}\right)+0.02\left(\mathrm{HBr}+\mathrm{O}_{3}\right)$ & B \\
\hline 12 & $\mathrm{BrO}+\mathrm{OH}$ & $\rightarrow$ & $\mathrm{Br}+\mathrm{HO}_{2}$ & A \\
\hline 13 & $\mathrm{Cl}+\mathrm{CH}_{4}$ & $\rightarrow$ & $\mathrm{HCl}+\mathrm{CH}_{3} \mathrm{O}_{2}$ & A \\
\hline 14 & $\mathrm{Cl}+\mathrm{Cl}_{2} \mathrm{O}_{2}$ & $\rightarrow$ & $3 \mathrm{Cl}$ & A \\
\hline 15 & $\mathrm{Cl}+\mathrm{ClONO}_{2}$ & $\rightarrow$ & $2 \mathrm{Cl}+\mathrm{NO}_{3}$ & A \\
\hline 16 & $\mathrm{Cl}+\mathrm{H}_{2}$ & $\rightarrow$ & $\mathrm{HCl}+\mathrm{H}$ & A \\
\hline 17 & $\mathrm{Cl}+\mathrm{H}_{2} \mathrm{O}_{2}$ & $\rightarrow$ & $\mathrm{HCl}+\mathrm{HO}_{2}$ & A \\
\hline 18 & $\mathrm{Cl}+\mathrm{HCHO}$ & $\rightarrow$ & $\mathrm{HCl}+\mathrm{CO}+\mathrm{HO}_{2}$ & A \\
\hline 19 & $\mathrm{Cl}+\mathrm{HO}_{2}$ & $\rightarrow$ & $\mathrm{HCl}+\mathrm{O}_{2}$ & A \\
\hline 20 & $\mathrm{Cl}+\mathrm{HO}_{2}$ & $\rightarrow$ & $\mathrm{ClO}+\mathrm{OH}$ & A \\
\hline 21 & $\mathrm{Cl}+\mathrm{HOCl}$ & $\rightarrow$ & $2 \mathrm{Cl}+\mathrm{OH}$ & B \\
\hline 22 & $\mathrm{Cl}+\mathrm{NO}_{3}$ & $\rightarrow$ & $\mathrm{ClO}+\mathrm{NO}_{2}$ & A \\
\hline 23 & $\mathrm{Cl}+\mathrm{O}_{3}$ & $\rightarrow$ & $\mathrm{ClO}+\mathrm{O}_{2}$ & A \\
\hline 24 & $\mathrm{Cl}+\mathrm{OClO}$ & $\rightarrow$ & $2 \mathrm{ClO}$ & A \\
\hline 25 & $2 \mathrm{ClO}$ & $\rightarrow$ & $\mathrm{Cl}_{2}+\mathrm{O}_{2} \rightarrow 2 \mathrm{Cl}$ & A \\
\hline 26 & $2 \mathrm{ClO}$ & $\rightarrow$ & $\mathrm{Cl}+\mathrm{ClO}_{2} \rightarrow 2 \mathrm{Cl}$ & A \\
\hline 27 & $2 \mathrm{ClO}$ & $\rightarrow$ & $\mathrm{Cl}+\mathrm{OClO}$ & A \\
\hline 28 & $\mathrm{ClO}+\mathrm{HO}_{2}$ & $\rightarrow$ & $\mathrm{HOCl}+\mathrm{O}_{2}$ & A \\
\hline 29 & $\mathrm{ClO}+\mathrm{CH}_{3} \mathrm{O}_{2}$ & $\rightarrow$ & $\mathrm{Cl}+\mathrm{HCHO}+\mathrm{HO}_{2}$ & $\mathrm{~B}$ \\
\hline 30 & $\mathrm{ClO}+\mathrm{NO}$ & $\rightarrow$ & $\mathrm{Cl}+\mathrm{NO}_{2}$ & A \\
\hline 31 & $\mathrm{ClO}+\mathrm{NO}_{3}$ & $\rightarrow$ & $\mathrm{Cl}+\mathrm{O}_{2}+\mathrm{NO}_{2}$ & A \\
\hline 32 & $2 \mathrm{HO}_{2}$ & $\rightarrow$ & $\mathrm{H}_{2} \mathrm{O}_{2}+\mathrm{O}_{2}$ & A \\
\hline 33 & $\mathrm{HO}_{2}+\mathrm{CH}_{3} \mathrm{O}_{2}$ & $\rightarrow$ & $\mathrm{O}_{2}+\mathrm{CH}_{3} \mathrm{OOH}$ & A \\
\hline 34 & $\mathrm{HO}_{2}+\mathrm{NO}$ & $\rightarrow$ & $\mathrm{OH}+\mathrm{NO}_{2}$ & B \\
\hline 35 & $\mathrm{HO}_{2}+\mathrm{NO}_{3}$ & $\rightarrow$ & $\mathrm{O}_{2}+0.5\left(\mathrm{HONO}_{2}+\mathrm{OH}+\mathrm{NO}_{2}\right)$ & A \\
\hline 36 & $\mathrm{HO}_{2}+\mathrm{O}_{3}$ & $\rightarrow$ & $\mathrm{OH}+2 \mathrm{O}_{2}$ & A \\
\hline 37 & $2 \mathrm{CH}_{3} \mathrm{O}_{2}$ & $\rightarrow$ & $2\left(\mathrm{HCHO}+\mathrm{HO}_{2}\right)+\mathrm{O}_{2}$ & B \\
\hline 38 & $\mathrm{CH}_{3} \mathrm{O}_{2}+\mathrm{NO}$ & $\rightarrow$ & $\mathrm{HCHO}+\mathrm{HO}_{2}+\mathrm{NO}_{2}$ & A \\
\hline 39 & $\mathrm{NO}+\mathrm{NO}_{3}$ & $\rightarrow$ & $2 \mathrm{NO}_{2}$ & A \\
\hline 40 & $\mathrm{NO}+\mathrm{O}_{3}$ & $\rightarrow$ & $\mathrm{NO}_{2}+\mathrm{O}_{2}$ & A \\
\hline 41 & $\mathrm{NO}_{2}+\mathrm{NO}_{3}$ & $\rightarrow$ & $\mathrm{NO}+\mathrm{NO}_{2}+\mathrm{O}_{2}$ & B \\
\hline 42 & $\mathrm{NO}_{2}+\mathrm{O}_{3}$ & $\rightarrow$ & $\mathrm{NO}_{3}+\mathrm{O}_{2}$ & A \\
\hline 43 & $\mathrm{NO}_{3}+\mathrm{Br}$ & $\rightarrow$ & $\mathrm{BrO}+\mathrm{NO}_{2}$ & A \\
\hline 44 & $\mathrm{NO}_{3}+\mathrm{HCHO}$ & $\rightarrow$ & $\mathrm{HONO}_{2}+\mathrm{CO}+\mathrm{HO}_{2}$ & A \\
\hline 45 & $\mathrm{O}\left({ }^{3} \mathrm{P}\right)+\mathrm{BrO}$ & $\rightarrow$ & $\mathrm{O}_{2}+\mathrm{Br}$ & A \\
\hline 46 & $\mathrm{O}\left({ }^{3} \mathrm{P}\right)+\mathrm{ClO}$ & $\rightarrow$ & $\mathrm{Cl}+\mathrm{O}_{2}$ & A \\
\hline 47 & $\mathrm{O}\left({ }^{3} \mathrm{P}\right)+\mathrm{H}_{2}$ & $\rightarrow$ & $\mathrm{OH}+\mathrm{H}$ & A \\
\hline 48 & $\mathrm{O}\left({ }^{3} \mathrm{P}\right)+\mathrm{H}_{2} \mathrm{O}_{2}$ & $\rightarrow$ & $\mathrm{OH}+\mathrm{HO}_{2}$ & A \\
\hline 49 & $\mathrm{O}\left({ }^{3} \mathrm{P}\right)+\mathrm{HBr}$ & $\rightarrow$ & $\mathrm{OH}+\mathrm{Br}$ & $\mathrm{B}$ \\
\hline 50 & $\mathrm{O}\left({ }^{3} \mathrm{P}\right)+\mathrm{HCHO}$ & $\rightarrow$ & $\mathrm{OH}+\mathrm{CO}+\mathrm{HO}_{2}$ & A \\
\hline 51 & $\mathrm{O}\left({ }^{3} \mathrm{P}\right)+\mathrm{HCl}$ & $\rightarrow$ & $\mathrm{OH}+\mathrm{Cl}$ & $\mathrm{B}$ \\
\hline 52 & $\mathrm{O}\left({ }^{3} \mathrm{P}\right)+\mathrm{HO}_{2}$ & $\rightarrow$ & $\mathrm{OH}+\mathrm{O}_{2}$ & A \\
\hline 53 & $\mathrm{O}\left({ }^{3} \mathrm{P}\right)+\mathrm{HOCl}$ & $\rightarrow$ & $\mathrm{OH}+\mathrm{ClO}$ & A \\
\hline 54 & $\mathrm{O}\left({ }^{3} \mathrm{P}\right)+\mathrm{NO}_{2}$ & $\rightarrow$ & $\mathrm{O}_{2}+\mathrm{NO}$ & A \\
\hline
\end{tabular}

Table 2. Continued.

\begin{tabular}{|c|c|c|c|c|}
\hline 55 & $\mathrm{O}\left({ }^{3} \mathrm{P}\right)+\mathrm{NO}_{3}$ & $\rightarrow$ & $\mathrm{O}_{2}+\mathrm{NO}_{2}$ & A \\
\hline 56 & $\mathrm{O}\left({ }^{3} \mathrm{P}\right)+\mathrm{O}_{3}$ & $\rightarrow$ & $2 \mathrm{O}_{2}$ & A \\
\hline 57 & $\mathrm{O}\left({ }^{3} \mathrm{P}\right)+\mathrm{OClO}$ & $\rightarrow$ & $\mathrm{O}_{2}+\mathrm{ClO}$ & A \\
\hline 58 & $\mathrm{O}\left({ }^{3} \mathrm{P}\right)+\mathrm{OH}$ & $\rightarrow$ & $\mathrm{O}_{2}+\mathrm{H}$ & A \\
\hline 59 & $\mathrm{O}\left({ }^{1} \mathrm{D}\right)+\mathrm{HBr}$ & $\rightarrow$ & $0.2\left[\mathrm{HBr}+\mathrm{O}\left({ }^{3} \mathrm{P}\right)\right]+0.8(\mathrm{OH}+\mathrm{Br})$ & A \\
\hline 60 & $\mathrm{O}\left({ }^{1} \mathrm{D}\right)+\mathrm{CH}_{4}$ & $\rightarrow$ & $0.9\left(\mathrm{OH}+\mathrm{CH}_{3} \mathrm{O}_{2}\right)+0.1\left(\mathrm{HCHO}+\mathrm{H}_{2}\right)$ & A \\
\hline 61 & $\mathrm{O}\left({ }^{1} \mathrm{D}\right)+\mathrm{CO}_{2}$ & $\rightarrow$ & $\mathrm{O}\left({ }^{3} \mathrm{P}\right)+\mathrm{CO}_{2}$ & A \\
\hline 62 & $\mathrm{O}\left({ }^{1} \mathrm{D}\right)+\mathrm{H}_{2}$ & $\rightarrow$ & $\mathrm{OH}+\mathrm{H}$ & A \\
\hline 63 & $\mathrm{O}\left({ }^{1} \mathrm{D}\right)+\mathrm{H}_{2} \mathrm{O}$ & $\rightarrow$ & $\mathrm{OH}+\mathrm{OH}$ & A \\
\hline 64 & $\mathrm{O}\left({ }^{1} \mathrm{D}\right)+\mathrm{HCl}$ & $\rightarrow$ & $0.09\left[\mathrm{O}\left({ }^{3} \mathrm{P}\right)+\mathrm{HCl}\right]$ & A \\
\hline 65 & $\mathrm{O}\left({ }^{1} \mathrm{D}\right)+\mathrm{N}_{2}$ & $\rightarrow$ & $\begin{array}{l}+0.24(\mathrm{H}+\mathrm{ClO})+0.67(\mathrm{OH}+\mathrm{Cl}) \\
\mathrm{O}\left({ }^{3} \mathrm{P}\right)+\mathrm{N}_{2}\end{array}$ & A \\
\hline 66 & $\mathrm{O}\left({ }^{1} \mathrm{D}\right)+\mathrm{N}_{2} \mathrm{O}$ & $\rightarrow$ & $0.42\left(\mathrm{~N}_{2}+\mathrm{O}_{2}\right)+1.16 \mathrm{NO}$ & B \\
\hline 67 & $\mathrm{O}\left({ }^{1} \mathrm{D}\right)+\mathrm{O}_{2}$ & $\rightarrow$ & $\mathrm{O}\left({ }^{3} \mathrm{P}\right)+\mathrm{O}_{2}$ & A \\
\hline 68 & $\mathrm{O}\left({ }^{1} \mathrm{D}\right)+\mathrm{O}_{3}$ & $\rightarrow$ & $1.5 \mathrm{O}_{2}+\mathrm{O}\left({ }^{3} \mathrm{P}\right)$ & A \\
\hline 69 & $\mathrm{OClO}+\mathrm{NO}$ & $\rightarrow$ & $\mathrm{NO}_{2}+\mathrm{ClO}$ & A \\
\hline 70 & $\mathrm{OH}+\mathrm{CH}_{4}$ & $\rightarrow$ & $\mathrm{H}_{2} \mathrm{O}+\mathrm{CH}_{3} \mathrm{O}_{2}$ & A \\
\hline 71 & $\mathrm{OH}+\mathrm{CO}$ & $\rightarrow$ & $\mathrm{H}+\mathrm{CO}_{2}$ & A \\
\hline 72 & $\mathrm{OH}+\mathrm{ClO}$ & $\rightarrow$ & $\mathrm{HO}_{2}+\mathrm{Cl}$ & B \\
\hline 73 & $\mathrm{OH}+\mathrm{ClO}$ & $\rightarrow$ & $\mathrm{HCl}+\mathrm{O}_{2}$ & B \\
\hline 75 & $\mathrm{OH}+\mathrm{H}_{2} \mathrm{O}_{2}$ & $\rightarrow$ & $\mathrm{H}_{2} \mathrm{O}+\mathrm{HO}_{2}$ & A \\
\hline 74 & $\mathrm{OH}+\mathrm{H}_{2}$ & $\rightarrow$ & $\mathrm{H}_{2} \mathrm{O}+\mathrm{H}$ & A \\
\hline 76 & $\mathrm{OH}+\mathrm{HBr}$ & $\rightarrow$ & $\mathrm{H}_{2} \mathrm{O}+\mathrm{Br}$ & A \\
\hline 77 & $\mathrm{OH}+\mathrm{HCHO}$ & $\rightarrow$ & $\mathrm{H}_{2} \mathrm{O}+\mathrm{CO}+\mathrm{HO}_{2}$ & A \\
\hline 78 & $\mathrm{OH}+\mathrm{HCl}$ & $\rightarrow$ & $\mathrm{H}_{2} \mathrm{O}+\mathrm{Cl}$ & A \\
\hline 79 & $\mathrm{OH}+\mathrm{HO}_{2}$ & $\rightarrow$ & $\mathrm{H}_{2} \mathrm{O}+\mathrm{O}_{2}$ & A \\
\hline 80 & $\mathrm{OH}+\mathrm{HOCl}$ & $\rightarrow$ & $\mathrm{ClO}+\mathrm{H}_{2} \mathrm{O}$ & B \\
\hline 81 & $\mathrm{OH}+\mathrm{HONO}_{2}$ & $\rightarrow$ & $\mathrm{H}_{2} \mathrm{O}+\mathrm{NO}_{3}$ & A \\
\hline 82 & $\mathrm{OH}+\mathrm{CH}_{3} \mathrm{OOH}$ & $\rightarrow$ & $\mathrm{H}_{2} \mathrm{O}+\mathrm{CH}_{3} \mathrm{O}_{2}$ & A \\
\hline 83 & $\mathrm{OH}+\mathrm{NO}_{3}$ & $\rightarrow$ & $\mathrm{HO}_{2}+\mathrm{NO}_{2}$ & $\mathrm{~B}$ \\
\hline 84 & $\mathrm{OH}+\mathrm{O}_{3}$ & $\rightarrow$ & $\mathrm{HO}_{2}+\mathrm{O}_{2}$ & A \\
\hline 85 & $\mathrm{OH}+\mathrm{OClO}$ & $\rightarrow$ & $\mathrm{HOCl}+\mathrm{O}_{2}$ & A \\
\hline 86 & $2 \mathrm{OH}$ & $\rightarrow$ & $\mathrm{H}_{2} \mathrm{O}+\mathrm{O}\left({ }^{3} \mathrm{P}\right)$ & B \\
\hline 87 & $\mathrm{O}\left({ }^{3} \mathrm{P}\right)+\mathrm{ClONO}_{2}$ & $\rightarrow$ & $\mathrm{ClO}+\mathrm{NO}_{3}$ & B \\
\hline 88 & $\mathrm{OH}+\mathrm{ClONO}_{2}$ & $\rightarrow$ & $\mathrm{HOCl}+\mathrm{NO}_{3}$ & B \\
\hline 89 & $\mathrm{OH}+\mathrm{HO}_{2} \mathrm{NO}_{2}$ & $\rightarrow$ & $\mathrm{H}_{2} \mathrm{O}+\mathrm{NO}_{2} \mathrm{O}_{2}$ & B \\
\hline 90 & $\mathrm{Cl}+\mathrm{CH}_{3} \mathrm{OOH}$ & $\rightarrow$ & $\mathrm{HCl}+\mathrm{CH}_{3} \mathrm{O}_{2}$ & B \\
\hline 91 & $\mathrm{CFCl}_{3}+\mathrm{O}\left({ }^{1} \mathrm{D}\right)$ & $\rightarrow$ & $2 \mathrm{Cl}+\mathrm{ClO}$ & B \\
\hline 92 & $\mathrm{CF}_{2} \mathrm{Cl}_{2}+\mathrm{O}\left({ }^{1} \mathrm{D}\right)$ & $\rightarrow$ & $\mathrm{Cl}+\mathrm{ClO}$ & B \\
\hline 93 & $\mathrm{CH}_{3} \mathrm{Br}+\mathrm{OH}$ & $\rightarrow$ & $\mathrm{Br}+\mathrm{OH}$ & B \\
\hline 94 & $\mathrm{CH}_{3} \mathrm{Br}+\mathrm{O}\left({ }^{1} \mathrm{D}\right)$ & $\rightarrow$ & $\mathrm{Br}+\mathrm{O}\left({ }^{3} \mathrm{P}\right)$ & B \\
\hline 95 & $\mathrm{CH}_{3} \mathrm{Br}+\mathrm{Cl}$ & $\rightarrow$ & $\mathrm{Br}+\mathrm{Cl}$ & B \\
\hline 96 & $\mathrm{~N}+\mathrm{O}_{2}$ & $\rightarrow$ & $\mathrm{NO}+\mathrm{O}\left({ }^{3} \mathrm{P}\right)$ & B \\
\hline 97 & $\mathrm{~N}+\mathrm{NO}$ & $\rightarrow$ & $\mathrm{N}_{2}+\mathrm{O}\left({ }^{3} \mathrm{P}\right)$ & B \\
\hline 98 & $\mathrm{~N}+\mathrm{NO}_{2}$ & $\rightarrow$ & $\mathrm{N}_{2} \mathrm{O}+\mathrm{O}\left({ }^{3} \mathrm{P}\right)$ & B \\
\hline 99 & $\mathrm{H}+\mathrm{O}_{3}$ & $\rightarrow$ & $\mathrm{OH}+\mathrm{O}_{2}$ & B \\
\hline 100 & $\mathrm{H}+\mathrm{HO}_{2}$ & $\rightarrow$ & $\begin{array}{l}1.38 \mathrm{OH}+0.29\left(\mathrm{H}_{2}+\mathrm{O}_{2}\right) \\
+0.02\left[\mathrm{O}\left({ }^{3} \mathrm{P}\right)+\mathrm{H}_{2} \mathrm{O}\right]\end{array}$ & B \\
\hline 101 & $\mathrm{H}+\mathrm{NO}_{2}$ & $\rightarrow$ & $\mathrm{OH}+\mathrm{NO}$ & B \\
\hline
\end{tabular}


Table 3. Termolecular reactions in Strat-UKCA. A=Atkinson et al. (2000). B=Sander et al. (2003).

\begin{tabular}{lllll}
\hline 1 & $\mathrm{BrO}_{2} \mathrm{NO}_{2}+\mathrm{M}$ & $\rightarrow$ & $\mathrm{BrONO}_{2}+\mathrm{M}$ & $\mathrm{A}$ \\
2,3 & $\mathrm{Cl}_{2} \mathrm{O}_{2}+\mathrm{M}$ & $\leftrightarrow$ & $2 \mathrm{ClO}+\mathrm{M}$ & $\mathrm{A}$ \\
4 & $\mathrm{ClO} \mathrm{NO}_{2}+\mathrm{M}$ & $\rightarrow$ & $\mathrm{ClONO}_{2}+\mathrm{M}$ & $\mathrm{A}$ \\
5 & $2 \mathrm{HO}_{2}+\mathrm{M}$ & $\rightarrow$ & $\mathrm{H}_{2} \mathrm{O}_{2}+\mathrm{O}_{2}+\mathrm{M}$ & $\mathrm{A}$ \\
6,7 & $\mathrm{HO}_{2}+\mathrm{NO}_{2}+\mathrm{M}$ & $\leftrightarrow$ & $\mathrm{HO}_{2} \mathrm{NO}_{2}+\mathrm{M}$ & $\mathrm{A}$ \\
8,9 & $\mathrm{~N}_{2} \mathrm{O}_{5}+\mathrm{M}$ & $\leftrightarrow$ & $\mathrm{NO}_{2}+\mathrm{NO}_{3}+\mathrm{M}$ & $\mathrm{A}$ \\
10 & $2 \mathrm{NO}+\mathrm{M}$ & $\rightarrow$ & $2 \mathrm{NO}_{2}+\mathrm{M}$ & $\mathrm{A}$ \\
11 & $\mathrm{O}\left({ }^{3} \mathrm{P}\right)+\mathrm{NO}+\mathrm{M}$ & $\rightarrow$ & $\mathrm{NO}_{2}+\mathrm{M}$ & $\mathrm{B}$ \\
12 & $\mathrm{O}\left({ }^{3} \mathrm{P}\right)+\mathrm{NO}_{2}+\mathrm{M}$ & $\rightarrow$ & $\mathrm{NO}_{3}+\mathrm{M}$ & $\mathrm{A}$ \\
13 & $\mathrm{O}\left({ }^{3} \mathrm{P}\right)+\mathrm{O}_{2}+\mathrm{M}$ & $\rightarrow$ & $\mathrm{O}_{3}+\mathrm{M}$ & $\mathrm{A}$ \\
14 & $\mathrm{O}\left({ }^{1} \mathrm{D}\right)+\mathrm{N}_{2}+\mathrm{M}$ & $\rightarrow$ & $\mathrm{N}_{2} \mathrm{O}+\mathrm{M}$ & $\mathrm{B}$ \\
15 & $\mathrm{OH}+\mathrm{NO}_{2}+\mathrm{M}$ & $\rightarrow$ & $\mathrm{HONO}_{2}+\mathrm{M}$ & $\mathrm{A}$ \\
16 & $2 \mathrm{OH}+\mathrm{M}$ & $\rightarrow$ & $\mathrm{H}_{2} \mathrm{O}_{2}+\mathrm{M}$ & $\mathrm{A}$ \\
17 & $\mathrm{H}+\mathrm{O}_{2}+\mathrm{M}$ & $\rightarrow$ & $\mathrm{HO}_{2}+\mathrm{M}$ & $\mathrm{B}$ \\
\hline
\end{tabular}

Chipperfield (1999). The abundance of nitric acid trihydrate (NAT) and mixed NAT/ice polar stratospheric clouds is calculated following Chipperfield (1999) assuming thermodynamic equilibrium with gas-phase $\mathrm{HNO}_{3}$ and water vapour. Also the treatment of reactions on liquid sulfate aerosol follows Chipperfield (1999).

Species with wet and dry deposition are indicated in Table 1; dry deposition applies to the bottom level of the model and deposition velocities are calculated in the same way as in Law et al. (1998) and Zeng and Pyle (2003). Wet deposition again follows Law et al. (1998). Lightning emissions of NO follow Price and Rind (1992) with total nitrogen produced by lightning scaled to $5 \operatorname{Tg}(\mathrm{N}) /$ year. Halogen source gases are treated in a simplified way, with only the major source species $\mathrm{CFCl}_{3}, \mathrm{CF}_{2} \mathrm{Cl}_{2}$, and $\mathrm{CH}_{3} \mathrm{Br}$ represented and lumped with other long-lived contributors, preserving numbers of chlorine and bromine atoms, respectively (Table 6; Chipperfield, 1999). Wet and dry deposition of inorganic halogen species are not represented; instead, these species are removed instantaneously at the surface. GHGs and ODSs are prescribed at the lowest model level; the boundary layer parameterization (Lock et al., 2000) propagates these signals throughout the boundary layer.

Nitric acid trihydrate (NAT) PSCs are assumed to be in equilibrium with gas phase $\mathrm{HNO}_{3}$. Sedimentation of PSCs is included in the model. Dehydration is handled as part of the MetUM hydrological cycle. Denitrification is prescribed in the same way as in Chipperfield (1999) with two different sedimentation velocities for pure NAT $(0.46 \mathrm{~mm} / \mathrm{s})$ and mixed ice/NAT $(17 \mathrm{~mm} / \mathrm{s})$.

The model is formulated in such a way that halogen loadings remain invariant under chemistry and are unaffected by dry and wet deposition. For a simulation with invariant lower boundary conditions and appropriate initializa-
Table 4. Photolysis reactions in Strat-UKCA. For details on the method see text. A=Chipperfield (1999), B=Law et al. (1998), $\mathrm{C}=$ Sander et al. (2003). "A, C" means that the cross section follows $\mathrm{A}$ and the branching ratio follows $\mathrm{C}$. "A, B" means that the photolysis rate follows A above $200 \mathrm{hPa}$, and $\mathrm{B}$ below $300 \mathrm{hPa}$, with a linear transition inbetween. "A, B, C" means the same as "A, B" but with the branching ratio following $\mathrm{C}$.

\begin{tabular}{|c|c|c|c|c|}
\hline 1 & $\mathrm{BrCl}+h v$ & $\rightarrow$ & $\mathrm{Br}+\mathrm{Cl}$ & A \\
\hline 2 & $\mathrm{BrO}+h v$ & $\rightarrow$ & $\mathrm{Br}+\mathrm{O}\left({ }^{3} \mathrm{P}\right)$ & A \\
\hline 3 & $\mathrm{BrONO}_{2}+h v$ & $\rightarrow$ & $0.29\left(\mathrm{Br}+\mathrm{NO}_{3}\right)+0.71\left(\mathrm{BrO}+\mathrm{NO}_{2}\right)$ & $\mathrm{A}, \mathrm{C}$ \\
\hline 4 & $\mathrm{O}_{2}+h v$ & $\rightarrow$ & $2 \mathrm{O}\left({ }^{3} \mathrm{P}\right)$ & $\mathrm{A}, \mathrm{B}, \mathrm{C}$ \\
\hline 5 & $\mathrm{O}_{2}+h v$ & $\rightarrow$ & $\mathrm{O}\left({ }^{3} \mathrm{P}\right)+\mathrm{O}\left({ }^{1} \mathrm{D}\right)$ & $\mathrm{A}, \mathrm{C}$ \\
\hline 6 & $\mathrm{O}_{3}+h v$ & $\rightarrow$ & $\mathrm{O}_{2}+\mathrm{O}\left({ }^{3} \mathrm{P}\right)$ & $\mathrm{A}, \mathrm{B}$ \\
\hline 7 & $\mathrm{O}_{3}+h v$ & $\rightarrow$ & $\mathrm{O}_{2}+\mathrm{O}\left({ }^{1} \mathrm{D}\right)$ & A, B \\
\hline 8 & $\mathrm{OClO}+h v$ & $\rightarrow$ & $\mathrm{O}\left({ }^{3} \mathrm{P}\right)+\mathrm{ClO}$ & A \\
\hline 9 & $\mathrm{NO}+h v$ & $\rightarrow$ & $\mathrm{N}+\mathrm{O}\left({ }^{3} \mathrm{P}\right)$ & A \\
\hline 10 & $\mathrm{NO}_{2}+h v$ & $\rightarrow$ & $\mathrm{NO}+\mathrm{O}\left({ }^{3} \mathrm{P}\right)$ & $\mathrm{A}, \mathrm{B}$ \\
\hline 11 & $\mathrm{NO}_{3}+h v$ & $\rightarrow$ & $\mathrm{NO}+\mathrm{O}_{2}$ & $\mathrm{~A}, \mathrm{~B}$ \\
\hline 12 & $\mathrm{NO}_{3}+h v$ & $\rightarrow$ & $\mathrm{NO}_{2}+\mathrm{O}\left({ }^{3} \mathrm{P}\right)$ & A, B \\
\hline 13 & $\mathrm{HOBr}+h v$ & $\rightarrow$ & $\mathrm{OH}+\mathrm{Br}$ & A \\
\hline 14 & $\mathrm{HONO}_{2}+h v$ & $\rightarrow$ & $\mathrm{NO}_{2}+\mathrm{OH}$ & A, B \\
\hline 15 & $\mathrm{HO}_{2} \mathrm{NO}_{2}+h v$ & $\rightarrow$ & $\begin{array}{l}0.67\left(\mathrm{NO}_{2}+\mathrm{HO}_{2}\right)+ \\
0.33\left(\mathrm{NO}_{3}+\mathrm{OH}\right)\end{array}$ & $\mathrm{A}, \mathrm{B}, \mathrm{C}$ \\
\hline 16 & $\mathrm{~N}_{2} \mathrm{O}+h v$ & $\rightarrow$ & $\mathrm{N}_{2}+\mathrm{O}\left({ }^{1} \mathrm{D}\right)$ & A \\
\hline 17 & $\mathrm{~N}_{2} \mathrm{O}_{5}+h v$ & $\rightarrow$ & $\mathrm{NO}_{2}+\mathrm{NO}_{3}$ & A, B \\
\hline 18 & $\mathrm{H}_{2} \mathrm{O}+h v$ & $\rightarrow$ & $\mathrm{OH}+\mathrm{H}$ & A \\
\hline 19 & $\mathrm{H}_{2} \mathrm{O}_{2}+h v$ & $\rightarrow$ & $2 \mathrm{OH}$ & A, B \\
\hline 20 & $\mathrm{ClONO}_{2}+h v$ & $\rightarrow$ & $\mathrm{Cl}+\mathrm{NO}_{3}$ & A, C \\
\hline 21 & $\mathrm{ClONO}_{2}+h v$ & $\rightarrow$ & $\mathrm{ClO}+\mathrm{NO}_{2}$ & $\mathrm{~A}, \mathrm{C}$ \\
\hline 22 & $\mathrm{HCl}+h v$ & $\rightarrow$ & $\mathrm{H}+\mathrm{Cl}$ & A \\
\hline 23 & $\mathrm{HOCl}+h v$ & $\rightarrow$ & $\mathrm{OH}+\mathrm{Cl}$ & A \\
\hline 24 & $\mathrm{Cl}_{2} \mathrm{O}_{2}+h v$ & $\rightarrow$ & $2 \mathrm{Cl}+\mathrm{O}_{2}$ & A \\
\hline 25 & $\mathrm{HCHO}+h v$ & $\rightarrow$ & $\mathrm{H}+\mathrm{CO}+\mathrm{HO}_{2}$ & A, B \\
\hline 26 & $\mathrm{HCHO}+h v$ & $\rightarrow$ & $\mathrm{H}_{2}+\mathrm{CO}$ & A, B \\
\hline 27 & $\mathrm{CH}_{3} \mathrm{OOH}+h v$ & $\rightarrow$ & $\mathrm{HCHO}+\mathrm{HO}_{2}+\mathrm{OH}$ & $\mathrm{A}, \mathrm{B}$ \\
\hline 28 & $\mathrm{CFCl}_{3}+h v$ & $\rightarrow$ & $3 \mathrm{Cl}$ & A \\
\hline 29 & $\mathrm{CF}_{2} \mathrm{Cl}_{2}+h v$ & $\rightarrow$ & $2 \mathrm{Cl}$ & A \\
\hline 30 & $\mathrm{CH}_{3} \mathrm{Br}+h v$ & $\rightarrow$ & $\mathrm{Br}$ & A \\
\hline 31 & $\mathrm{CH}_{4}+h v$ & $\rightarrow$ & $\mathrm{CH}_{3} \mathrm{O}_{2}+\mathrm{H}$ & A \\
\hline 32 & $\mathrm{CO}_{2}+h v$ & $\rightarrow$ & $\mathrm{CO}+\mathrm{O}\left({ }^{3} \mathrm{P}\right)$ & A \\
\hline
\end{tabular}

Table 5. Heterogeneous reactions in Strat-UKCA. Rates are from Chipperfield (1999).

\begin{tabular}{llll}
\hline 1 & $\mathrm{ClONO}_{2}+\mathrm{H}_{2} \mathrm{O}$ & $\rightarrow$ & $\mathrm{HOCl}+\mathrm{HONO}_{2}$ \\
2 & $\mathrm{ClONO}_{2}+\mathrm{HCl}$ & $\rightarrow$ & $\mathrm{Cl}_{2} \mathrm{O}_{2}+\mathrm{HONO}_{2}$ \\
3 & $\mathrm{HOCl}+\mathrm{HCl}$ & $\rightarrow$ & $\mathrm{Cl}_{2} \mathrm{O}_{2}+\mathrm{H}_{2} \mathrm{O}$ \\
4 & $\mathrm{~N}_{2} \mathrm{O}_{5}+\mathrm{H}_{2} \mathrm{O}$ & $\rightarrow$ & $\mathrm{HONO}_{2}+\mathrm{HONO}_{2}$ \\
5 & $\mathrm{~N}_{2} \mathrm{O}_{5}+\mathrm{HCl}$ & $\rightarrow$ & $\mathrm{OClO}_{+} \mathrm{NO}_{2}+\mathrm{HONO}_{2}$ \\
\hline
\end{tabular}

tion, this should lead to a uniform, invariant halogen loading throughout the course of the integration. However, the advection scheme (Priestley, 1993) is somewhat non-linear in tracers and requires non-linear tracer mass fixing. This step introduces non-conservation of chemical elements. To 
Table 6. Lumping of halogen source gases.

\begin{tabular}{l|l}
\hline $\mathrm{CFCl}_{3}$ & $\mathrm{CFCl}_{3}, \mathrm{CCl}_{4}, \mathrm{CH}_{3} \mathrm{Cl}, \mathrm{CH}_{3} \mathrm{CCl}_{3}, \mathrm{CH}_{3} \mathrm{CFCl}_{2}, \mathrm{CH}_{3} \mathrm{CF}_{2} \mathrm{Cl}, \mathrm{CF}_{2} \mathrm{ClBr}$ \\
$\mathrm{CF}_{2} \mathrm{Cl}_{2}$ & $\mathrm{CF}_{2} \mathrm{Cl}_{2}, \mathrm{CF}_{2} \mathrm{ClCFCl}_{2},\left(\mathrm{CF}_{2} \mathrm{Cl}_{2}, \mathrm{C}_{2} \mathrm{~F}_{5} \mathrm{Cl}_{2} \mathrm{CHF}_{2} \mathrm{Cl}\right.$ \\
$\mathrm{CH}_{3} \mathrm{Br}$ & $\mathrm{CH}_{3} \mathrm{Br}, \mathrm{CF}_{2} \mathrm{ClBr}, \mathrm{CF}_{3} \mathrm{Br},\left(\mathrm{CF}_{2} \mathrm{Br}\right)_{2}, \mathrm{CF}_{2} \mathrm{Br}_{2}$ \\
\hline
\end{tabular}

Table 7. (a) Surface boundary conditions needed for chemistry: Volume mixing ratios (VMRs) for $\mathrm{CH}_{4}, \mathrm{~N}_{2} \mathrm{O}$, and halogen source gases. $\mathrm{Cl}_{\mathrm{y}}$ and $\mathrm{Br}_{\mathrm{y}}$ denote total chlorine and total bromine, respectively. (b) Surface VMRs for the CFCs and $\mathrm{CO}_{2}$ (needed for radiation). 3-dimensional distributions for the CFCs are obtained by rescaling the lumped fields.

(a)

\begin{tabular}{lllll|ll}
\hline $\mathrm{CH}_{4}$ & $\mathrm{~N}_{2} \mathrm{O}$ & $\mathrm{CFCl}_{3}$ & $\mathrm{CF}_{2} \mathrm{Cl}_{2}$ & $\mathrm{CH}_{3} \mathrm{Br}$ & $\mathrm{Cl}_{\mathrm{y}}$ & $\mathrm{Br}_{\mathrm{y}}$ \\
\hline $1.77 \mathrm{E}-6$ & $316 \mathrm{E}-9$ & $632 \mathrm{E}-12$ & $723 \mathrm{E}-12$ & $17.5 \mathrm{E}-12$ & $3.34 \mathrm{E}-9$ & $17.5 \mathrm{E}-12$ \\
\hline
\end{tabular}

(b)

\begin{tabular}{lll}
\hline $\mathrm{CFCl}_{3}$ & $\mathrm{CF}_{2} \mathrm{Cl}_{2}$ & $\mathrm{CO}_{2}$ \\
\hline $262 \mathrm{E}-12$ & $539 \mathrm{E}-12$ & $369 \mathrm{E}-6$ \\
\hline
\end{tabular}

circumvent this problem we introduce total chlorine and total bromine as advected tracers. These tracers then do not have sharp gradients in the stratosphere. For transport they replace the most abundant inorganic forms of chlorine and bromine, $\mathrm{HCl}$ and $\mathrm{BrO}$. The model then well preserves total chlorine and total bromine. A total odd nitrogen tracer, replacing $\mathrm{NO}_{2}$, is also introduced, which also includes the fraction of $\mathrm{N}_{2} \mathrm{O}$ that goes on to form odd nitrogen (6.9\%). Due to the special treatment of water vapour (see above) hydrogen is not explicitly conserved in the model; this feature can be included once the tropical tropopause warm bias has been reduced. This aspect of the model is expected to improve in a planned future version with a new advection scheme which will be linear in tracers.

\section{The simulation}

In the following we present the results of a 30-year timeslice simulation of Strat-UKCA, following the definition of the REF-B0 experiment of CCMVal. In this experiment, forcings represent perpetual year-2000 conditions. Boundary conditions and global abundances, respectively, of GHGs and ODSs are listed in Table 7. $\mathrm{CO}_{2}$ is assumed uniform with an abundance of 369 ppmv. Aircraft emissions of NO and surface emissions of $\mathrm{NO}, \mathrm{CO}$, and $\mathrm{HCHO}$ are the average over the years 1998, 1999, and 2000 emissions taken from the RETRO database (Schultz et al., 2007). The total halogen loadings are around $3.4 \mathrm{ppbv}$ for chlorine and
$17.5 \mathrm{pptv}$ for bromine. We prescribe a perpetual year 2000 aerosol surface area density updated from SPARC (2006), as described by Eyring et al. (2008); this affects reactions 3 and 4 in Table 5. Aerosols are at background levels, i.e., volcanic eruptions are not considered in the simulation. Note that bromine species considered in REF-B0 deliberately exclude very short-lived bromine source gases which would contribute 3-8 pptv to stratospheric bromine (WMO, 2007). Species with feedback into the radiation are highlighted in Table 1. For radiation, the $\mathrm{CFCs}\left(\mathrm{CFCl}_{3}\right.$ and $\left.\mathrm{CF}_{2} \mathrm{Cl}_{2}\right)$ are scaled to their surface abundance, following the $\mathrm{A} 1 \mathrm{~b}$ scenario (Houghton et al., 2001), without lumping. The first 10 years of the simulation, during which the model settles down, are ignored; results pertain to the last 20 years of the run.

\section{Model performance}

\subsection{Dynamical aspects}

\subsubsection{Mean temperature, winds and humidity}

Figure 1 shows the 20-year temperature climatology produced by the model, which is compared to a climatology derived from the ERA-40 reanalysis data set (Uppala et al., 2005), using the years 1979 to 2001 . The model satisfactorily reproduces tropospheric zonal-mean temperatures, and in the stratosphere the southern polar vortex is well represented. The northern polar vortex above $100 \mathrm{hPa}$ is also well captured. Elsewhere, some biases remain, e.g., in the upper stratosphere (above $10 \mathrm{hPa}$ ), and around $100 \mathrm{hPa}$ year-round in the tropics. The warm bias around $100 \mathrm{hPa}$ means that without additional constraints too much water would enter the stratosphere. As an aside, versions of the MetUM with prescribed ozone do not exhibit any appreciable bias in this region, suggesting that this is an ozone-sensitive result. However, the realistic temperatures above Antarctica mean that there can be substantial chlorine activation in the southern polar vortex, allowing us to assess the model's performance in reproducing Antarctic ozone.

A depiction of zonal winds in the model (Fig. 2) reveals that the positions of major features, such as the subtropical jets and the polar jets, are well captured by the model. Also the subtropical jets appear as isolated maxima in the zonal wind, separated from the polar jets, with a realistic amplitude. 

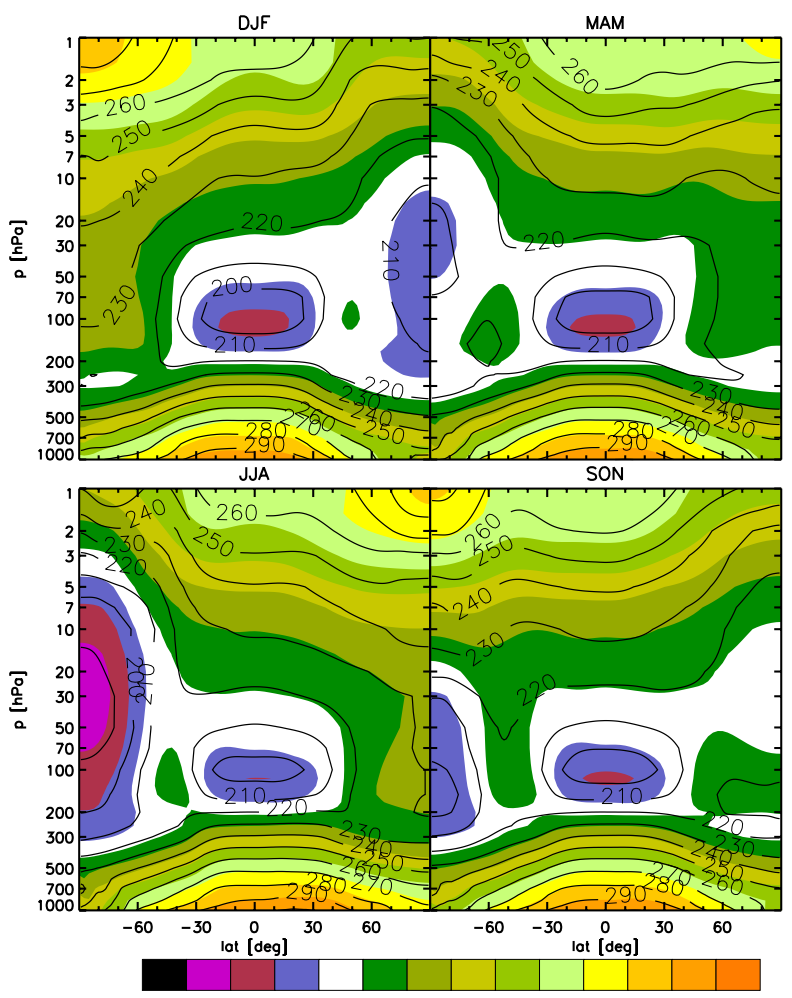

$\begin{array}{lllllllllllllll}170 & 180 & 190 & 200 & 210 & 220 & 230 & 240 & 250 & 260 & 270 & 280 & 290 & 300 & 310\end{array}$

Fig. 1. Multiannual, seasonal- and zonal-mean temperatures in $\mathrm{K}$ in Strat-UKCA (colours) and in the ERA-40 dataset using the years 1979-2001 (contours).

Figure 3 indicates that water vapour is generally well represented. ERA-40 has got a slightly more pronounced dehydration during Antarctic winter; also dehydration does not extend below $100 \mathrm{hPa}$. The upper-stratospheric abundance of water vapour is very similar to the ERA-40 climatology. Also the position of the transition to tropospheric humidity (around $6 \mathrm{ppmv}$ ) is quite similar between the two data sets. In the troposphere, away from the tropical UTLS region there is good agreement. In the upper tropical troposphere, around $200 \mathrm{hPa}$, ERA-40 predicts somewhat more water vapour than Strat-UKCA. Note that the seasonal cycle of water vapour around $70 \mathrm{hPa}$ in the tropics evident in ERA-40 is suppressed in the model by artificially prescribing water vapour there (Sect. 2).

\subsubsection{The Quasi-Biennial Oscillation (QBO)}

An analysis of equatorial winds (Fig. 4, left) reveals that there is a well-formed oscillation in the lower stratosphere, with amplitudes of 10 to $20 \mathrm{~m} / \mathrm{s}$ for the westerly phase and -30 to $-40 \mathrm{~m} / \mathrm{s}$ for the easterly phase. Both compare well with observations (Naujokat, 1986). Its period length of around 4.5 years however is significantly too long, compared with an observed average periodicity of the Quasi-Biennial Oscillation (QBO) of around 27 months. The periodicity is substantially longer than the one found in the equivalent

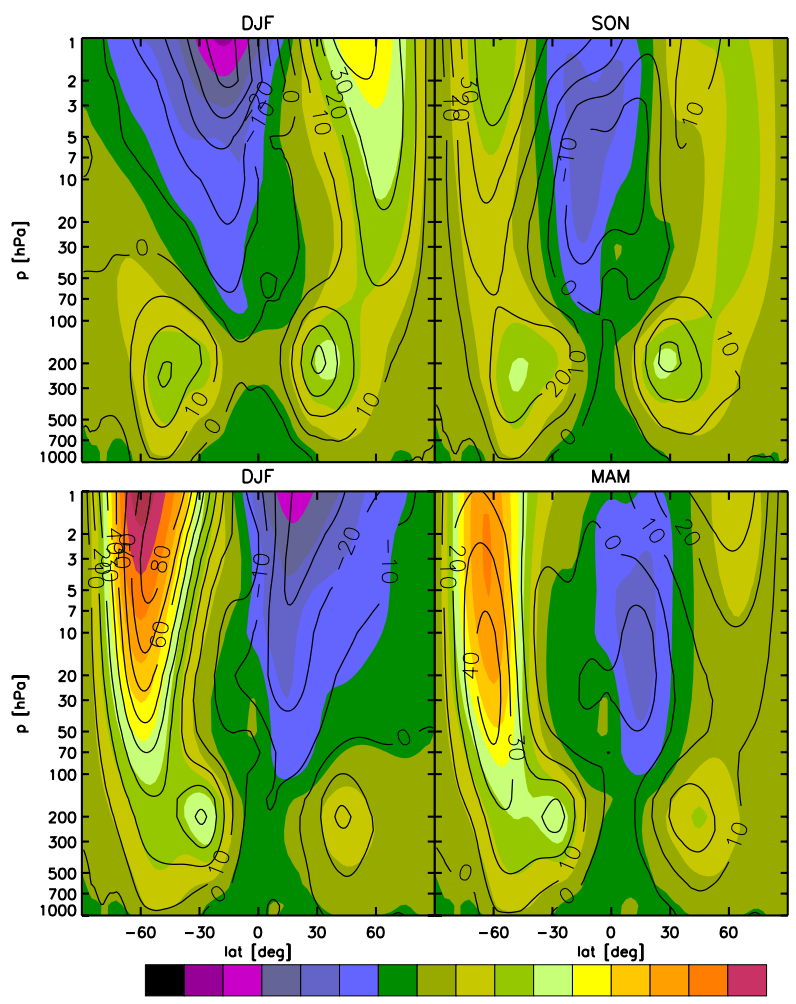

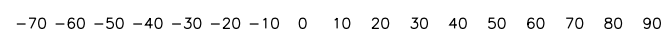

Fig. 2. Same as Fig. 1 but for zonal wind, in $\mathrm{m} / \mathrm{s}$.
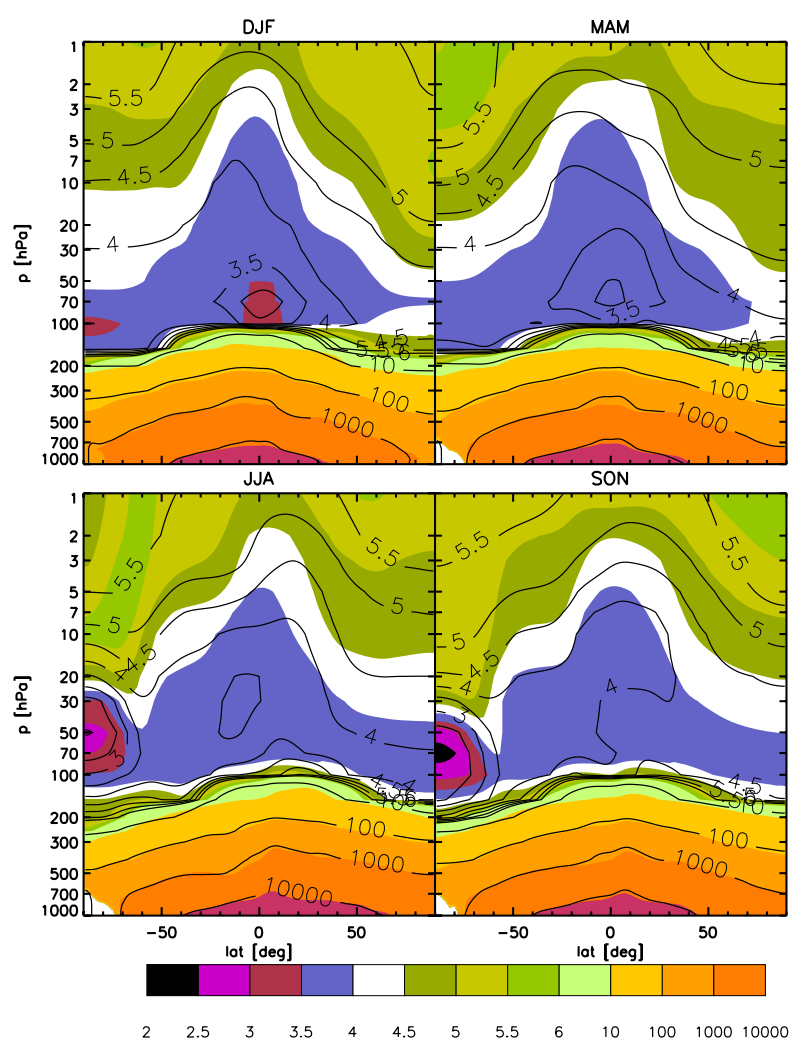

Fig. 3. Same as Fig. 1 but for water vapour volume mixing ratio, in parts per million by volume (ppmv). 

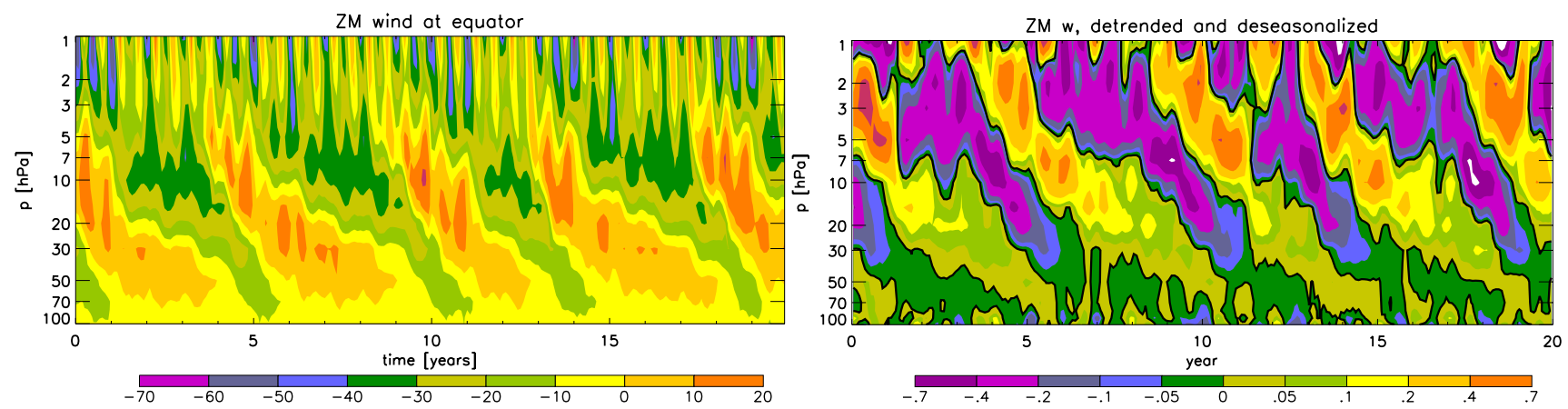

Fig. 4. (left) Monthly- and zonal-mean zonal wind $u$ in Strat-UKCA at the Equator, in $\mathrm{m} / \mathrm{s}$. (right) Deseasonalized, detrended and smoothed zonal-mean vertical wind $w^{*}$ at the Equator, in $\mathrm{mm} / \mathrm{s}$.

version without interactive chemistry, indicating a sensitivity to ozone (Butchart et al., 2003). It can be changed by varying the source strength in the spectral gravity wave deposition; this re-tuning has not been done for this model version. The presence of the oscillation however sets the model apart from the majority of the models compared by Eyring et al. (2006) that do not have an internally generated QBO.

The QBO is known to modulate upwelling in the tropics. Following Fleming et al. (2002), Fig. 4 (right) shows the detrended, deseasonalized, and smoothed vertical winds $w^{*}$ at the Equator throughout the integration. A comparison with Fig. 4 (left) shows that $w^{*}$ correlates very well with zonal winds, as in Fleming et al. (2002); also the typical peak-topeak amplitude (Fig. 4, right) compares well with Fig. 1 of Fleming et al. (2002).

\subsubsection{The polar vortices}

Figure 5 displays the probability density function (PDF) $P(A)$ of an area $A$ ocurring with temperatures below $195 \mathrm{~K}$ at $50 \mathrm{hPa}$. It is evaluated for both Strat-UKCA and ERA40 and separately for both hemispheres, excluding areas equatorwards of $\pm 45^{\circ}$. The PDF is calculated from daily snapshots of temperature at 00:00 UTC. For the Arctic, Fig. 5 suggests that small to medium-size vortices (less than $10 \times 10^{12} \mathrm{~m}^{2}$ ) are well represented, but the probability for large vortices is underestimated. For the Antarctic, both in Strat-UKCA and ERA-40 there are preferred sizes for the polar vortex. In the ERA-40 data this is around $23 \times 10^{12} \mathrm{~m}^{2}$. Strat-UKCA underestimates this with around $19 \times 10^{12} \mathrm{~m}^{2}$, with consequences for the simulation of the Antarctic ozone hole.

The timing of the onset of Antarctic summer, as indicated by a reversal from westerlies to easterlies at the latitude of the polar jet, has been challenging for models to reproduce correctly (Eyring et al., 2006, see Fig. 6), with many models producing a late onset of summer. The zonal-mean winds turn to easterlies starting aloft and propagating downwards

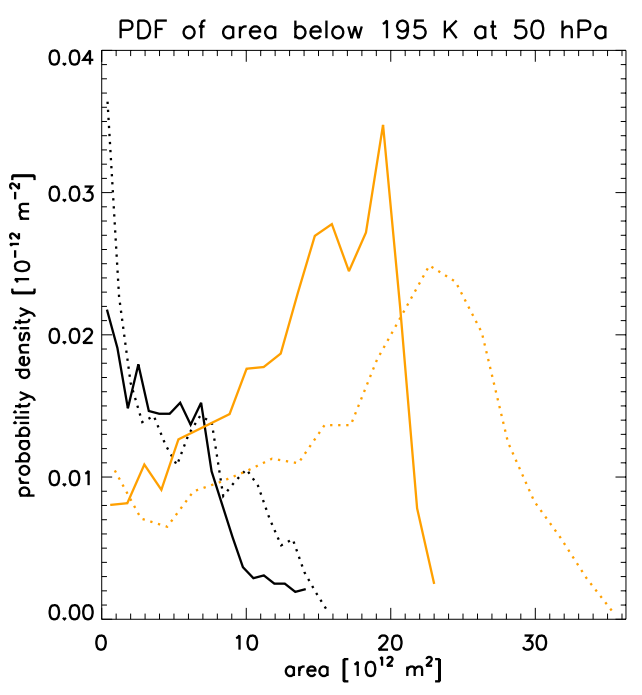

Fig. 5. The PDF for, at any time of the year, the area with temperatures below $195 \mathrm{~K}$ at $50 \mathrm{hPa}$. The PDF is constructed from daily snapshots at 00:00 UTC. Solid: Strat-UKCA. Dotted: ERA-40 for the years 1979-2002. Black: Northern Hemisphere (latitude $>45^{\circ}$ ). Orange: Southern Hemisphere (latitude $<-45^{\circ}$ ).

during the course of the months of November to January. The timing of breakup in our model compares favourably with the ERA-40 data set (Fig. 6), with deviations from the ERA-40 mean limited to less than the standard deviation throughout the depth of the domain.

\subsubsection{Age of air and the tape recorder signal}

The age of air (Hall et al., 1999) is defined here as the time passed since an air parcel last resided in the troposphere. It is calculated as an advected tracer, set to 0 below $2 \mathrm{~km}$ of altitude and increased at every timestep by the timestep length. For analysis purposes we subtract from this tracer the average 

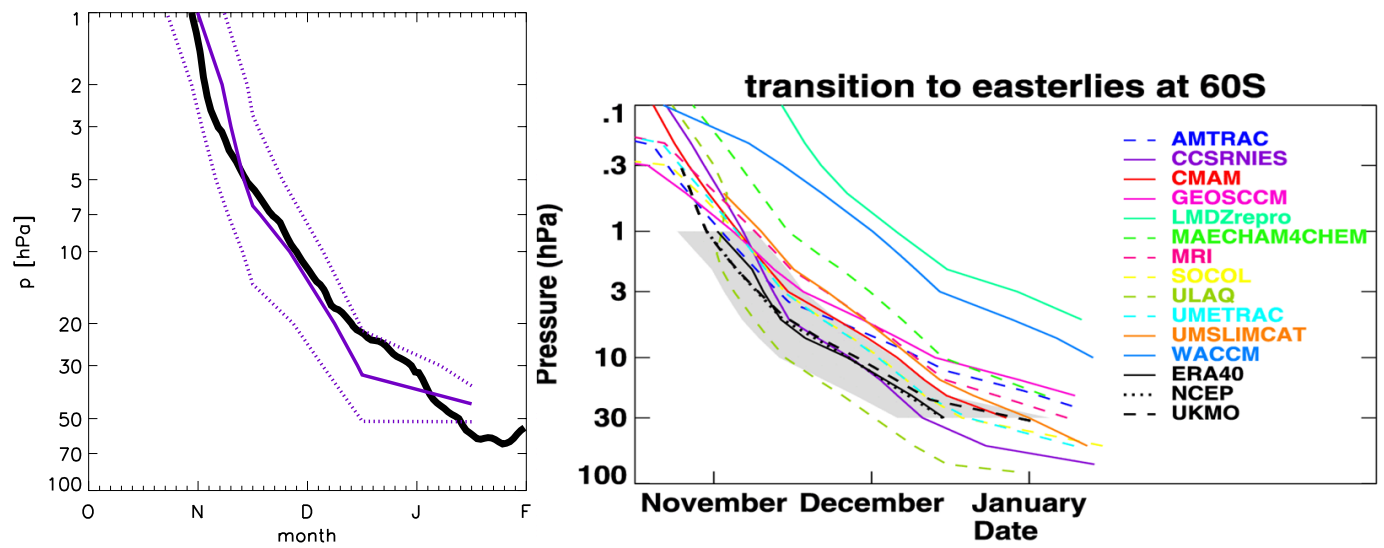

Fig. 6. Timing of the transition of the zonal-mean zonal wind from westerlies to easterlies at $60^{\circ} \mathrm{S}$. Left: Black contour: UKCA mean wind. Violet solid: ERA-40 mean wind. Dashed: ERA-40 plus and minus the standard deviation of ERA-40. Ticks mark the beginning of the month. Right: Same for 12 models and 3 analyses (Fig. 2 of Eyring et al., 2006). Reproduced with kind permission by AGU.
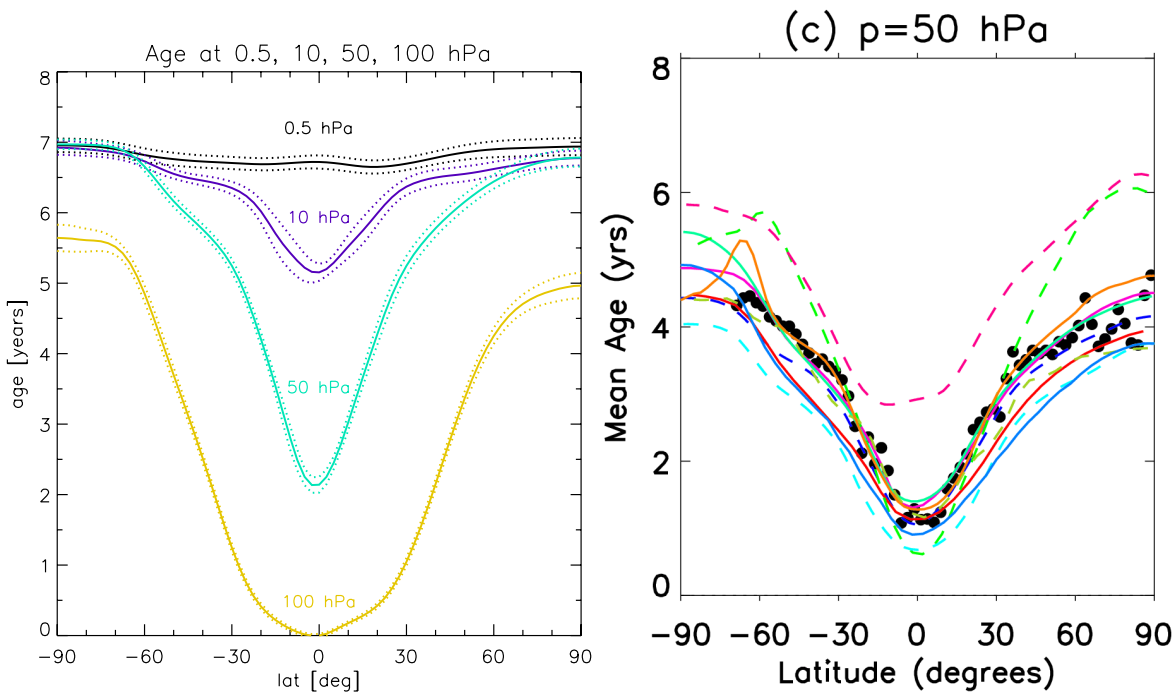

Fig. 7. Left: Annual-zonal mean age of air in Strat-UKCA at 100, 50, 10, and $0.5 \mathrm{hPa}$, with the mean age at the Equator at $100 \mathrm{hPa}$ defined as 0 . Dotted lines indicate the age plus and minus its standard deviation. Right: Annual-zonal mean age at $50 \mathrm{hPa}$ from ER-2 observations of $\mathrm{CO}_{2}$ and from a variety of models (Fig. 10c of Eyring et al., 2006). Reproduced with kind permission by AGU.

age at the Equator at $100 \mathrm{hPa}$. Figure 7 shows the 20-year mean age, with the interannual standard deviation, at different pressures, compared to observations and models. As expected, due to the periodic forcings the interannual variability of annual-mean age, expressed by the standard deviation, is typically just a few months; this also indicates that any trend due to insufficient spin-up must be insignificant. There is about a 2-year difference in age in the tropics between 100 and $50 \mathrm{hPa}$, which is quite large compared to measurements and most models. The difference between mean equatorial and south-polar age at $50 \mathrm{hPa}$ of around 4.7 years is also larger than suggested by Eyring et al. (2006). It appears that upward motion in the tropical pipe is too slow, leading to these problems. Consequences for chemistry and radiation, and a possible link to the tropical-tropopause warm bias, are discussed in the subsequent sections.

Figure 8 shows the tape recorder signal in Strat-UKCA. By construction there is no tape recorder in the modelled water vapour signal; however, the annually periodic forcing of trace gases means there is a small tape recorder signal e.g. in the total bromine field, caused by the decrease of total bromine by about $2 \%$ during the year 2000 . We compare the result to the tape recorder signals seen in the Halogen Occultation Experiment (HALOE)/Microwave Limb Sounder 

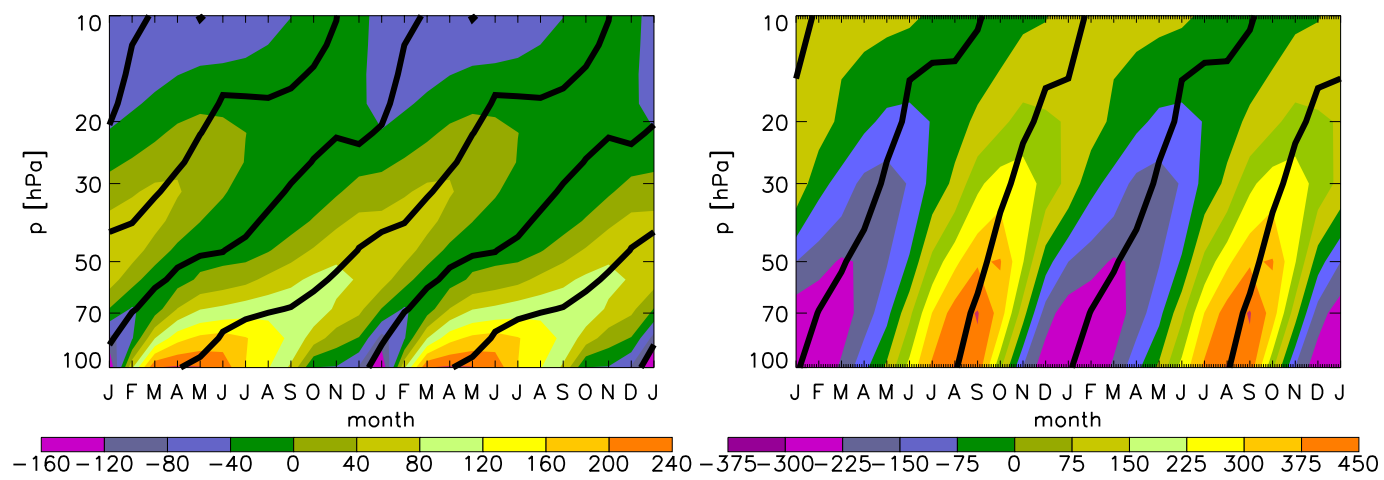

Fig. 8. Left: Multiannual- and zonal-mean total bromine VMR at the Equator, minus global-mean bromine, times $10^{15}$ (ppfv), from StratUKCA. Right: Multiannual- and zonal-mean water vapour volume mixing ratio at the Equator, minus the mean equatorial water profile, in ppbv, from ERA-40 (1979-2002). Shown are two annual cycles.

(MLS) climatology (Fig. 8 of Eyring et al., 2006) and in the ERA-40 water vapour. There is a considerable difference in the speed of upward propagation between these two data sets, with HALOE/MLS suggesting slower upward propagation than ERA-40. Resolving this discrepancy is beyond the scope of this paper; however, there is a possibility that stratospheric water vapour in ERA-40 may be insufficiently constrained by observations and may mainly reflect an ECMWF model property. The HALOE/MLS tape recorder signal suggests an age difference between 100 and $10 \mathrm{hPa}$ in the tropics of around 20 months; Strat-UKCA is largely in agreement with this number. Considering the aforementioned problems with age of air, further comparisons with independent data would be beneficial, e.g. the satellite products compared by Chiou et al. (1992).

\subsection{Chemical constituents}

\subsubsection{Ozone}

Figure 9 shows the modelled zonal-mean ozone column latitude-time section, with the SBUV/TOMS climatology (Stolarski and Frith, 2006) superimposed. All the major features in the diagram look similar to the climatology and their timing is captured realistically. In the tropics, both the magnitude of the column and its standard deviation (2-5 Dobson Units, DU, not shown) compare very well with observations. In northern high latitudes, Strat-UKCA overestimates the springtime ozone maximum by 60 to $80 \mathrm{DU}$, but also the minimum in summer is slightly overestimated. In southern midlatitudes, we find again a year-round overestimation of the ozone column by 20 to $60 \mathrm{DU}$. Antarctic ozone reaches mean values of less than $180 \mathrm{DU}$ in October. Observations suggest a slightly deeper mean ozone hole for present-day conditions, of less than 150 DU. However, the contrast with midlatitudes is quite realistic. The standard deviation maximizes at $50 \mathrm{DU}$ in early spring in the Arctic and late spring in

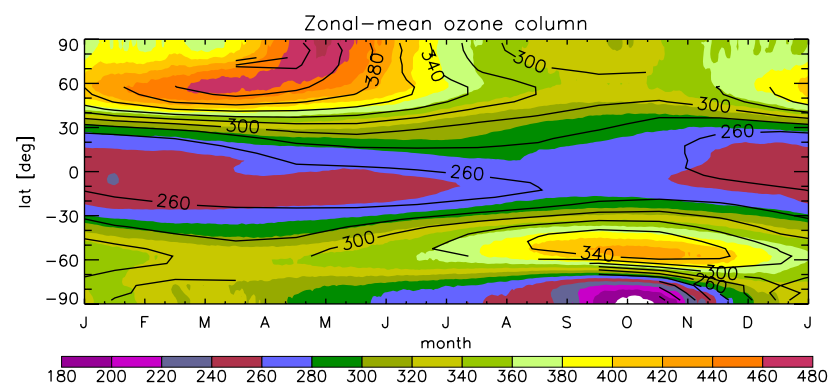

Fig. 9. Multiannual- and zonal-mean ozone column (Dobson Units). Colours: Strat-UKCA, with daily resolution. Contours: TOMS/SBUV climatology, with monthly resolution.

the Antarctic, respectively, mainly reflecting the differences in the life cycles of the polar vortices. A comparison with Fig. 14 of Eyring et al. (2006) suggests that in the tropics and mid-latitudes Strat-UKCA is within the range spanned by other models; for polar latitudes the comparison is inappropriate because Eyring et al. (2006) evaluate a transient simulation with significant changes in polar halogen loadings whereas here we study a time-slice experiment with invariant, historically high halogen loadings.

A cross section of ozone reveals that again the basic features of the stratospheric ozone distribution are well captured by the UKCA model, for example in the months of September and February (Fig. 10). The ozone maximum in the tropics at $10 \mathrm{hPa}$ is slightly underestimated versus the HALOE/MLS climatology (Russell et al., 1993). Between 10 and $1 \mathrm{hPa}$ UKCA-Strat also underestimates the ozone abundance by about $1 \mathrm{ppmv}$. At heights lower than the maximum however the model generally overestimates the ozone abundance. This is particularly evident around the tropical tropopause, versus the ozone climatology by Fortuin and 

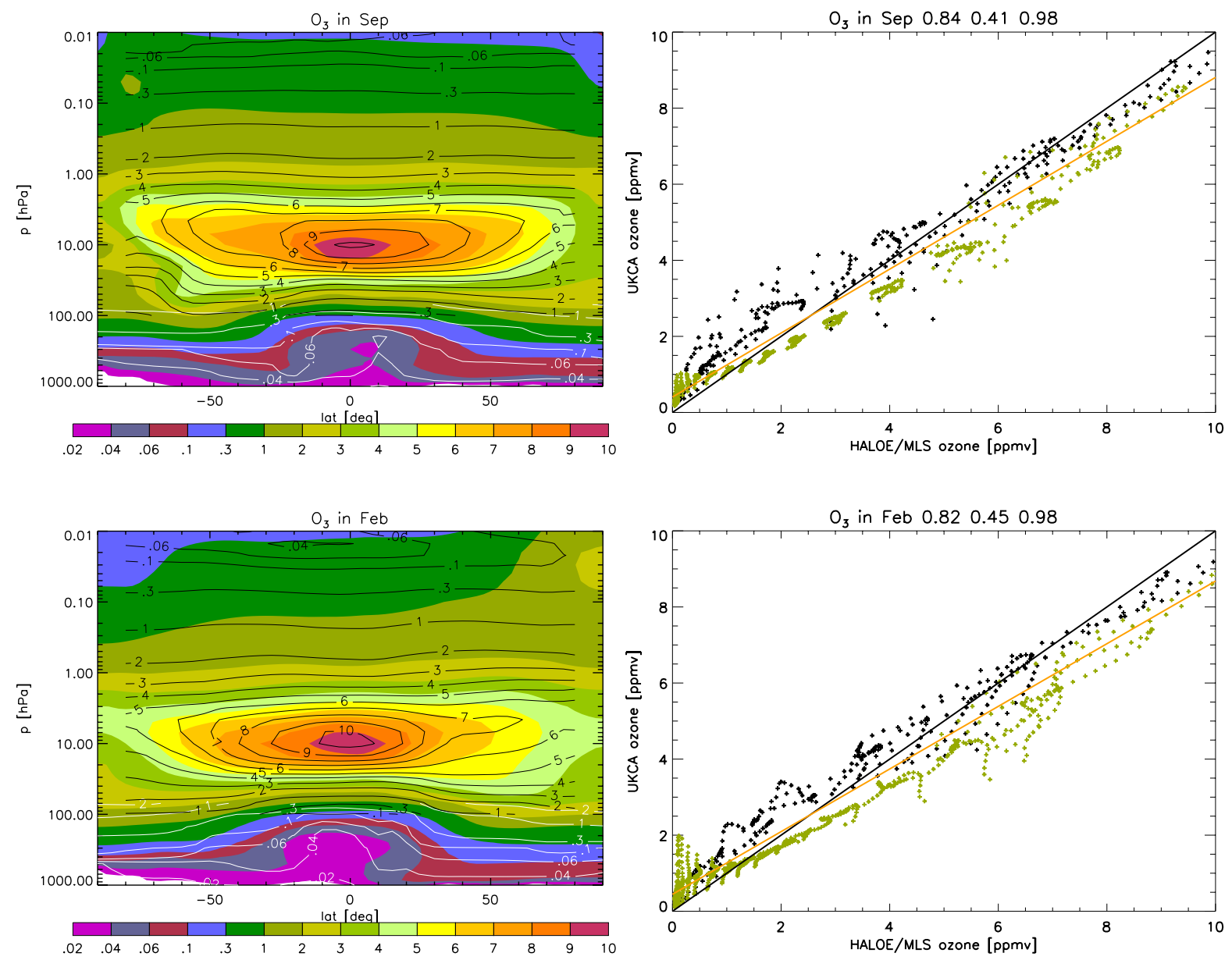

Fig. 10. Multiannual-, monthly-, and zonal-mean ozone in ppmv in (top) September and (bottom) February. (left) Colours: Strat-UKCA. Black contours: HALOE/MLS climatology. White contours: The Fortuin and Langematz (1995) climatology, restricted to $p>70 \mathrm{hPa}$ (right) Scatter plot of Strat-UKCA versus HALOE/MLS ozone. Black line: 1:1 line. Black symbols: Pressure $p \geq 10 \mathrm{hPa}$. Green symbols; $p<10 \mathrm{hPa}$. Orange line: Linear regression fit. The parameters of the regression (slope, axis intercept, in ppmv, and the correlation coefficient) are stated in the titles of the plots (Russell et al., 1993).

Langematz (1995). This feature possibly reflects the slow updraft found before in the tropical lower stratosphere. There may also be excessive ozone production here due to insufficient UV absorption at higher levels where ozone is underestimated. Elsewhere in the free troposphere, in the extratropics the model generally seems to overestimate ozone. The Antarctic ozone hole is present in the data; however, the depth is underestimated with ozone mixing ratios not dropping below 1 ppmv below $40 \mathrm{hPa}$, unlike suggested by the HALOE/MLS climatology. Figure 13 of Eyring et al. (2006) suggests that most CCMs, like ours, overestimate ozone in the lower-stratosphere region.

A detailed evaluation of the tropospheric performance of UKCA is the subject of part 2 (Sect. 1).

\subsubsection{Methane and nitrous oxide}

For $\mathrm{CH}_{4}$ we perform a comparison versus the HALOE/Cyrogenic Limb Array Etalon Spectrometer (CLAES) climatology (Fig. 11; Kumer et al., 1993). In general, the two $\mathrm{CH}_{4}$ distributions are quite similar, although with some important differences. In the tropics, modelled $\mathrm{CH}_{4}$ appears to fall off too quickly with height. In the southern polar vortex, a tongue of very methane-depleted air extends down from the mesosphere and, e.g. between 100 and $1 \mathrm{hPa}$, depresses the $\mathrm{CH}_{4}$ mixing ratio below values suggested by HALOE/CLAES. For $\mathrm{N}_{2} \mathrm{O}$, essentially the same comments apply. In the southern polar vortex, the drop from 250 to $50 \mathrm{ppbv}$ occurs between 150 and $50 \mathrm{hPa}$ whereas the climatology suggests this drop should happen between 100 and $25 \mathrm{hPa}$. These findings suggest overly strong 

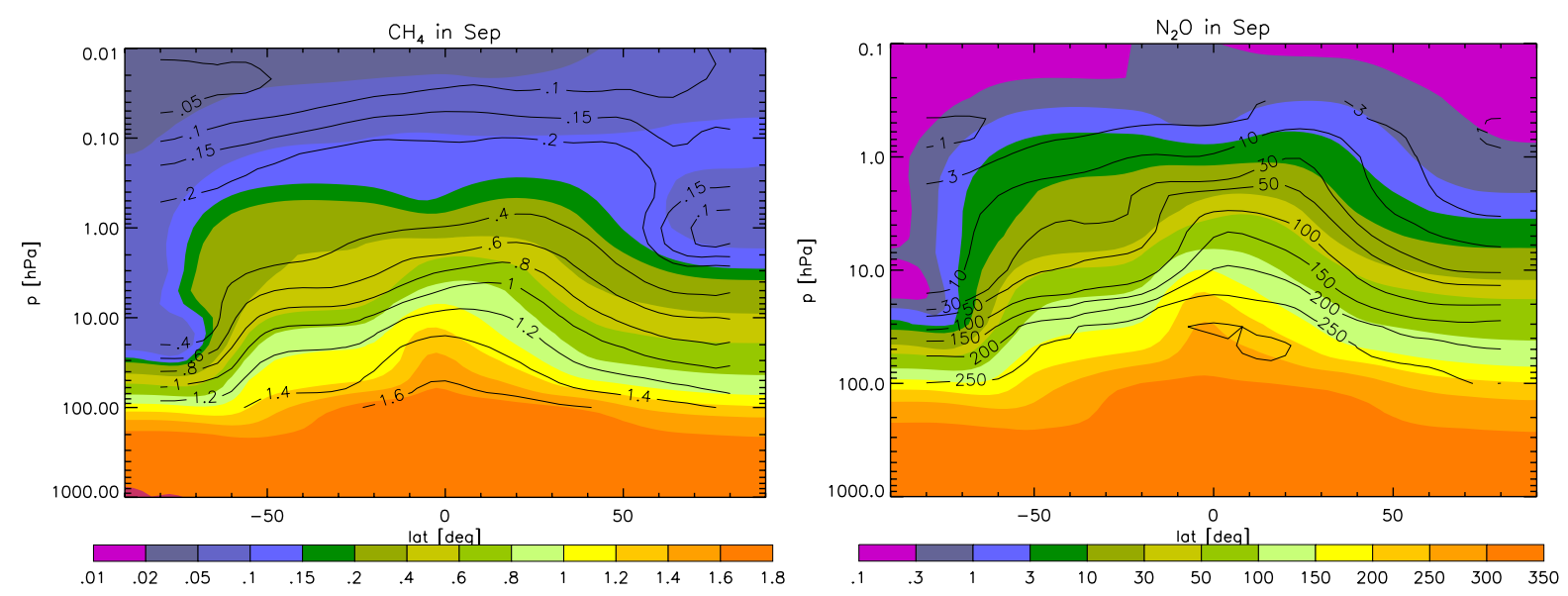

Fig. 11. Multiannual-, monthly-, and zonal-mean (left) $\mathrm{CH}_{4}$ in ppmv and (right) $\mathrm{N}_{2} \mathrm{O}$ in ppbv, in September. Colours: Strat-UKCA. Contours: $\mathrm{CH}_{4}$ : HALOE/CLAES climatology. $\mathrm{N}_{2} \mathrm{O}$ : CLAES climatology.
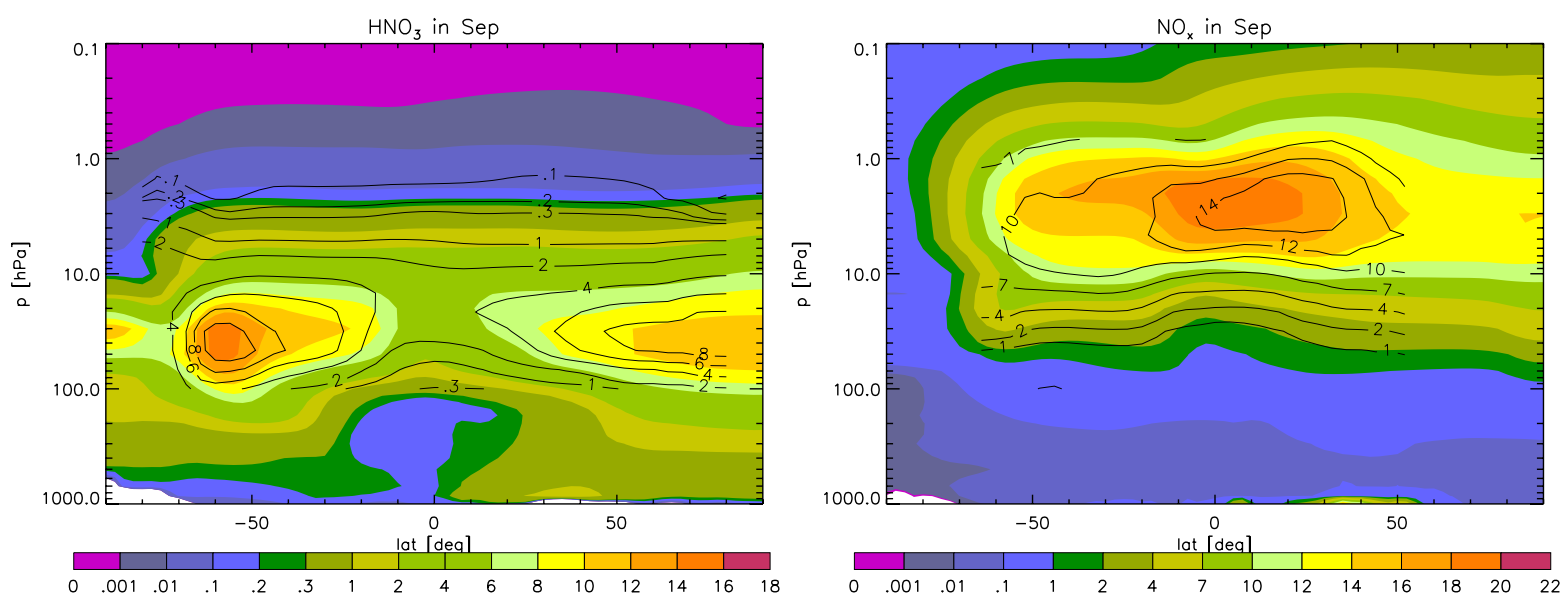

Fig. 12. Multiannual-, monthly-, and zonal-mean (left) $\mathrm{HNO}_{3}$ and (right) $\mathrm{NO}_{\mathrm{x}}=\mathrm{NO}_{2}+\mathrm{NO}$ in September, in ppbv. Colours: Strat-UKCA. Contours: $\mathrm{HNO}_{3}$ : CLAES climatology. $\mathrm{NO}_{\mathrm{x}}$ : HALOE climatology (average of sunrise and sunset data).

subsidence of air of mesospheric origin in the Antarctic polar vortex; the steep decline of methane in the tropical pipe is also related to the slow ascent in the tropical pipe.

\subsubsection{Odd nitrogen}

Odd nitrogen in the stratosphere mostly results from $\mathrm{N}_{2} \mathrm{O}$ oxidation, with (in our model) $6.9 \%$ of $\mathrm{N}_{2} \mathrm{O}$ forming $\mathrm{NO}_{\mathrm{y}}$, the rest returning $\mathrm{N}_{2}$. In the lower stratosphere, the dominant form of odd nitrogen is $\mathrm{HNO}_{3}$. Generally, compared to the CLAES climatology the shape of the distribution of nitric acid is well represented but the model somewhat overestimates its abundance (Fig. 12). Above $10 \mathrm{hPa}$, the dominant form of odd nitrogen is $\mathrm{NO}_{\mathrm{x}}\left(=\mathrm{NO}+\mathrm{NO}_{2}\right)$. A reference HALOE $\mathrm{NO}_{\mathrm{x}}$ climatology is constructed by taking the sum of the four sunrise and sunset $\mathrm{NO}$ and $\mathrm{NO}_{2}$ climatologies, divided by 2 . In comparison with this reference, the model gets the shape of the distribution about right but the magnitude is overestimated, reflecting the too rapid decline of $\mathrm{N}_{2} \mathrm{O}$ with altitude.

\subsubsection{Hydrogen chloride}

The dominant form of inorganic chlorine in much of the stratosphere is $\mathrm{HCl}$. A comparison of modelled versus HALOE HCl (Fig. 13) indicates that the model captures the general features of the $\mathrm{HCl}$ distribution rather well, particularly the latitudinal gradients across the subtropical jets. In the upper stratosphere, the model has systematically somewhat more $\mathrm{HCl}$ than the climatology. HALOE covers the 

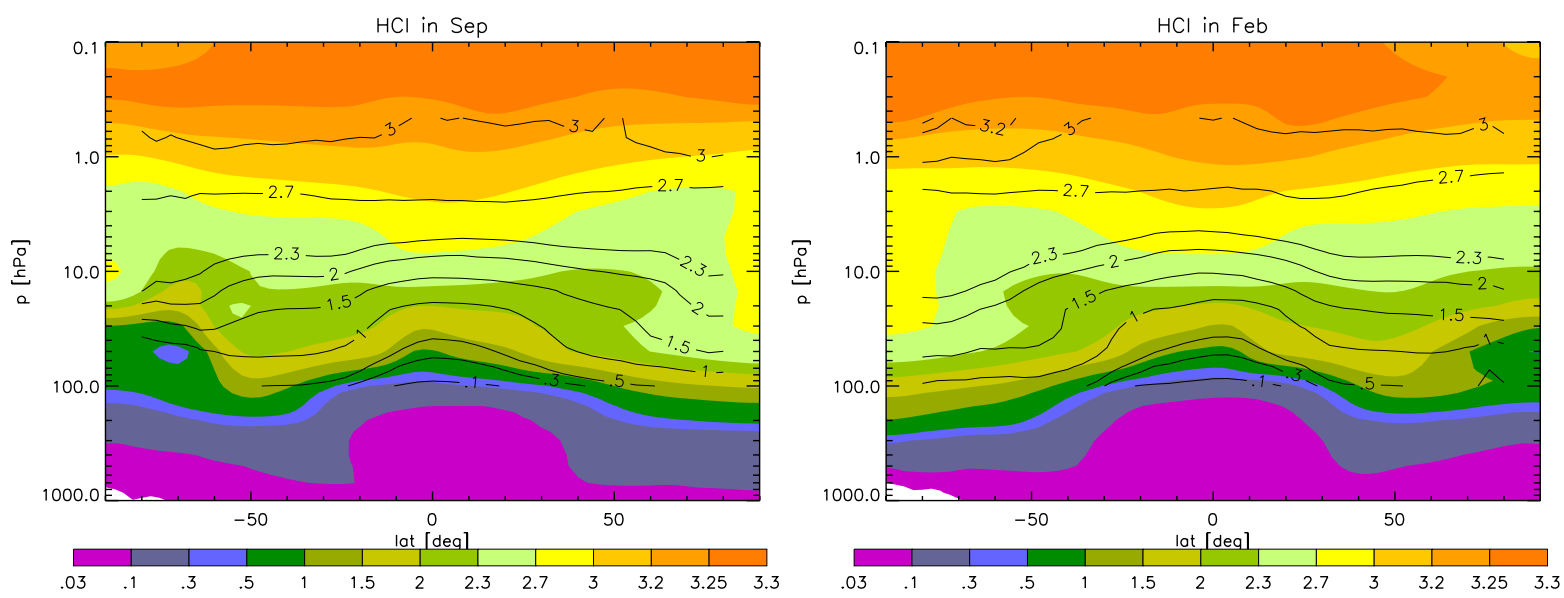

Fig. 13. Multiannual-, monthly-, and zonal-mean $\mathrm{HCl}$ in ppbv in (left) September and (right) February. Colours: Strat-UKCA. Contours: HALOE climatology.

Table 8. Global atmospheric lifetimes of long-lived species, in years. The uncertainty indicates the interannual standard deviation of the annual-mean lifetimes. *excluding the terrestrial sink.

\begin{tabular}{lllll}
\hline species & $\mathrm{N}_{2} \mathrm{O}$ & $\mathrm{CFCl}_{3}$ & $\mathrm{CF}_{2} \mathrm{Cl}_{2}$ & $\mathrm{CH}_{4}$ \\
Strat-UKCA & $161 \pm 3$ & $88 \pm 3$ & $146 \pm 3$ & $9.07 \pm 0.03$ \\
Houghton et al. (2001) & 120 & 45 & 100 & $8.9^{*}$ \\
\hline
\end{tabular}

period of 1978-1993, during which time the average chlorine loading was indeed lower than the loading imposed for Strat-UKCA (Table 7). Also note the evidence for chlorine activation in southern high latitudes, e.g., the isolated minimum of $\mathrm{HCl}$ at $70^{\circ} \mathrm{S}$ and $50 \mathrm{hPa}$. In February there is evidence for weaker chlorine activation in the Arctic, with a localized minimum of $\mathrm{HCl}$ forming between 50 and $90 \mathrm{hPa}$ in the Arctic, in good agreement with HALOE.

\subsubsection{Lifetimes of long-lived species}

The lifetime of long-lived species is defined here as the mean abundance of a given species during a model year, divided by the total throughput through all loss channels during this year. Table 8 summarizes the findings. The $\mathrm{CH}_{4}$ lifetime compares favourably to Houghton et al. (2001) indicating that tropospheric $\mathrm{OH}$ abundances are broadly correct. For the other long-lived tracers with large tropospheric sinks $\left(\mathrm{CH}_{3} \mathrm{Br}, \mathrm{H}_{2}\right)$ important surface sinks are excluded from the budget, leading to a substantial overestimation of the lifetimes. The errors in $\mathrm{N}_{2} \mathrm{O}$ and the CFCs reflect a genuine problem of this model version. These species are almost exclusively photochemically destroyed in the stratosphere; the very slow updraft in the tropical pipe noted earlier (Sect. 4.1.4) implies that these species are not destroyed quickly enough.

\subsection{Climate-chemistry coupling}

Braesicke and Pyle (2003) find a strong anticorrelation between the northern polar ozone column and the strength of the polar jet, peaking (in their model) at a correlation coefficient of -0.91 in January. Here we assess the performance of Strat-UKCA in this respect, versus available observational data. Note that satellite data do not cover the Arctic in January; we focus here on March when the northern polar vortex is still intact and satellite used here achieves a partial coverage of the polar region. Figure 14 shows the Arctic ozone column in March, as a function of a measure of the strength of the polar jet. The correlation coefficient of -0.76 is almost the same as that derived from NIMBUS-7/TOMS data (Heath and Park, 1978) and ERA-40 reanalyses (Uppala et al., 2005) for the same variables. This suggests that despite the obvious offset of around $50 \mathrm{DU}$ produced by the model the coupling between ozone column and jet strength is well represented in the model. Strat-UKCA actually produces strong anticorrelations for all winter months. As an aside, Morgenstern et al. (2008) use Strat-UKCA to study a world with 9 ppbv of total chlorine in the atmosphere (2.7 times the amount used here); they find that this relationship has broken down at $9 \mathrm{ppbv}$ of total chlorine.

The Eliassen-Palm (EP) flux (Andrews et al., 1987) is a measure of the heat flux towards the poles. Randel et al. (2002) find a see-saw of large correlations between the vertical component of the EP-flux and ozone column changes in January-April at high northern latitudes, and an anticorrelation in the tropics. Our results (Fig. 15) qualitatively agree with Randel et al. (2002), in that we find high positive correlations at high latitudes, particularly in winter, and some significant anticorrelations during some months in the tropics; in detail on the other hand there are differences between their model results and ours, regarding both the seasonality and the 


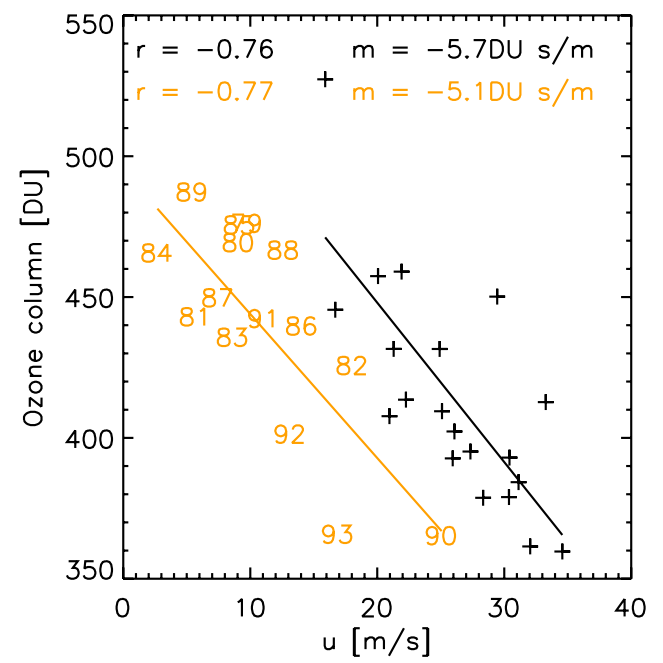

Fig. 14. Monthly-zonal-mean March zonal wind $u$ at $60^{\circ} \mathrm{N}$ and $100 \mathrm{hPa}$, versus monthly-zonal-mean March ozone column at $77.5^{\circ} \mathrm{N}$. Linear regressions are superimposed. Black symbols: Strat-UKCA. Orange numbers: Observations, marked by the years of the 20th century. Zonal winds are from ERA-40 analyses. Ozone columns are constructed from daily NIMBUS-7 TOMS (Heath and Park, 1978) total ozone maps. Note that at $77.5^{\circ} \mathrm{N}$ TOMS measurements start on 6 or 7 March, so the mean is from 6 or 7 March to 31 March. $r$ stands for the correlation coefficient, $m$ for the linear regression coefficient.

geographical distrubution of significant positive or negative correlations. A verification of EP flux-ozone column change correlations using observations is complicated by a need for high temporal resolution of meteorological analyses and is thus beyond the scope of this paper.

\section{Synthesis of model performance and outlook}

The model comparison versus satellite and other climatological datasets suggests that in many respects the model performs quite well. With the exception of tropical tropopause temperatures, in the multiannual mean all basic meteorological fields analyzed here compare favourably with ERA40. The size of the Antarctic polar vortex is underestimated by around $3 \times 10^{12} \mathrm{~m}^{2}$, but the timing of its disappearance in spring compares very well with ERA-40. October mean Antarctic ozone columns drop to 160 to $180 \mathrm{DU}$, indicating a somewhat weak ozone depletion in the Antarctic. The Arctic polar vortex is well captured; only the probability of rare large vortices (greater than $10^{13} \mathrm{~m}^{2}$ ) is underestimated. The model produces a QBO but with a periodicity of around 4.5 years which is too large compared to observations. Age of air is older than suggested by observations and most other models, with the maximum age difference between the tropical tropopause and $0.5 \mathrm{hPa}$ reaching 7 years. This prop-

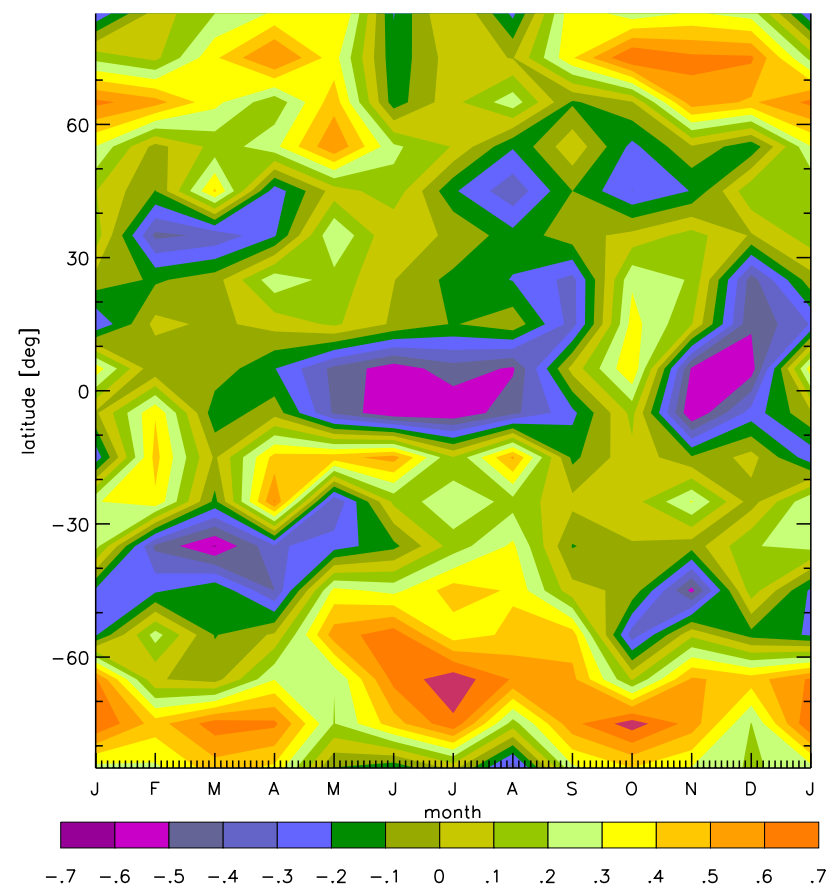

Fig. 15. Correlation coefficient, derived from Strat-UKCA, of the mean change of zonal-mean ozone column in a month, $\Delta \mathrm{O}_{3} / \Delta t$, with the vertical component of the EP flux at $100 \mathrm{hPa}$. The data have been binned in $10^{\circ}$ latitude bands for the analysis.

erty is also reflected in an upward propagation of the tape recorder signal which is slower than in the ERA-40 reanalyses. It however compares favourably to the UARS/MLS climatology. This aspect requires further investigation. The slow upwelling causes an overestimation of chemical lifetimes of species with dominant stratospheric sinks $\left(\mathrm{N}_{2} \mathrm{O}\right.$ and the CFCs). The methane lifetime by contrast is well captured, indicating a broadly correct $\mathrm{OH}$ abundance in the troposphere. It appears from $\mathrm{N}_{2} \mathrm{O}$ and $\mathrm{CH}_{4}$ that subsidence over the South Pole in winter is too fast, possibly suppressing the signature of ozone loss by removing ozone-depleted air and activated chlorine from the ozone loss region. The model has a tendency to overestimate the abundance of ozone in middle and high latitudes generally, meaning that polar ozone depletion is likely to start off from a high starting point. Strat-UKCA produces a strong anticorrelation between Arctic ozone columns and the strength of the polar jet which is very similar to observations. An evaluation of EP fluxes reveals that seasonally at high latitudes there are strong correlations between the vertical component of the EP flux and changes in the ozone column. These two quantities also anticorrelate at lower latitudes. Qualitatively these findings are similar to literature assessments but there are important differences in seasonality.

We suggest that some of the problems described above may be tackled by addressing gravity wave deposition. The 
non-orographic part of it (Scaife et al., 2002) can be tuned to adjust the periodicity of the QBO. Temperature at the tropical tropopause may be more sensitive to the orographic component (Webster et al., 2003). Increasing the upwelling in this region might simultaneously reduce stratospheric age-of-air, remove some ozone from the tropopause region, thus cool this region, and reduce the lifetimes of long-lived gases. Retuning the model would need to broadly preserve temperatures in the polar vortices.

We conclude that for a contemporary atmosphere the model well reproduces the basic mean meteorological state of the stratosphere almost everywhere, with the exception of the tropical tropopause. The chemical fields analyzed here likewise resemble observations. The chemical-dynamical coupling that characterizes the Arctic polar vortex is well captured. A more comprehensive tropospheric chemistry (similar to Zeng and Pyle, 2003) and an interactive aerosol scheme (Spracklen et al., 2007) will be evaluated in parts 2 and 3 of this publication. Further developments will include nudging (Telford et al., 2008) and interactive photolysis (Neu et al., 2007).

Acknowledgements. This work is supported by the Natural Environment Research Council (NERC) through the NCAS initiative and by the European Commission under the Framework 6 SCOUT-O3 IP. F. M. O'Connor, C. E. Johnson and part of the development of UKCA were supported by the Joint DECC, Defra and MoD Integrated Climate Programme - DECC/Defra (GA01101), MoD (CBC/2B/0417_Annex C5). ECMWF ERA-40 data used in this study have been obtained from the ECMWF data server. We acknowledge the American Geophysical Union for use of copyrighted material.

Edited by: P. Joeckel

\section{References}

Andrews, D. G., Holton, J. R., and Leovy, C. B.: Middle Atmosphere Dynamics, Academic Press, 489 pp., 1987.

Atkinson, R., Baulch, D. L., Cox, R. A., Hampson, R. F., Kerr, J. A., Rossi, M. J., and Troe, J.: Evaluated kinetic and photochemical data for atmospheric chemistry: Supplement VIII, IUPAC Subcommittee on Gas Kinetic Data Evaluation and Atmospheric Chemistry, J. Phys. Chem. Ref. Data, 29, 167-266, 2000.

Bian, H. and Prather, M. J.: FAST-J2: Accurate simulation of stratospheric photolysis in global chemical models, J. Atmos. Chem., 41, 281-296, 2002.

Braesicke, P. and Pyle, J. A.: Changing ozone and changing circulation in northern mid-laitudes: Possible feedbacks?, Geophys. Res. Lett., 30(2), 1059, doi:10.1029/2002GL015973, 2003

Butchart, N., Scaife, A. A., Austin, J., Hare, S. H. E., and Knight, J. R.: Quasi-biennial oscillation in ozone in a coupled chemistry-climate model, J. Geophys. Res., 108(D15), 4486, doi:1029/2002JD003004, 2003.

Chiou, E. W., McCormick, M. P., McMaster, L. R., Chu, W. P., Larsen, J. C., Rind, D., and Oltmans, S.: Intercomparison of stratospheric water vapor observed by satellite experiments: Stratospheric Aerosol and Gas Experiment II versus Limb Infrared Monitor of the Stratosphere and Atmospheric Trace Molecule Spectroscopy, J. Geophys. Res., 98(D3), 4875-4887, 1992.

Chipperfield, M. P. and Pyle, J. A.: Model sensitivity studies of Arctic ozone depletion, Geophys. Res. Lett., 103(D1), 28389 28403, 1998.

Chipperfield, M. P.: Multiannual simulations with a threedimensional chemical transport model, J. Geophys. Res. 104(D1), 1781-1805, 1999.

Carver, G. D., Brown, P. D., and Wild, O.: The ASAD atmospheric chemistry integration package and chemical reaction database, Computer Phys. Comm., 105(2-3), 197-215, 1997.

Davies, T., Cullen, M. J., Malcolm, A. J., Mawson, M. H., Staniforth, A., White, A. A., and Wood, N.: A new dynamical core for the Met Office's global and regional modelling of the atmosphere, Qt. J. Roy. Meteor. Soc., 131, 1759-1782, doi:10.1256/qj.04.101, 2005.

Edwards, J. M. and Slingo, A.: Studies with a flexible new radiation code. I: Choosing a configuration for a large-scale model, Q. J. Roy. Meteor. Soc., 122, 689-719, 1996.

Eyring, V., Butchart, N., Waugh, D. W., et al.: Assessment of temperature, trace species, and ozone in chemistry-climate model simulations of the recent past, J. Geophys. Res., 111, D22308, doi:10.1029/2006JD007327, 2006.

Eyring, V., Chipperfield, M. P., Giorgetta, M. A., Kinnison, D. E., Manzini, E., Matthes, K., Newman, P. A., Pawson, S., Shepherd, T. G., and Waugh, D. W.: Overview of the new CCMVal reference and sensitivity simulations in support of upcoming ozone and climate assessments and the planned SPARC CCMVal, SPARC Newsletter, 30, 20-26, 2008.

Fleming, E. L., Jackman, C. H., Rosenfield, J. E., and Considine, D. B.: Two-dimensional model simulations of the QBO in ozone and tracers in the tropical stratosphere, J. Geophys. Res., 107(D23), 4665, doi:10.1029/2001JD001146, 2002.

Fortuin, J. P. F. and Langematz, U.: An update on the global ozone climatology and on concurrent ozone and temperature trends, Proceedings SPIE, Atmospheric Sensing and Modeling, 2311, 207-216, 1995.

Garcia, R. R., Marsh, D. R., Kinnison, D. E., Boville, B. A., and Sassi, F.: Simulation of secular trends in the middle atmosphere, 1950-2003, J. Geophys. Res., 112, D09301, doi:10.1029/2006JD007485, 2007.

Hall, T. M., Waugh, D. W., Boering, K. A., and Plumb, R. A.: Evaluation of transport in stratospheric models, J. Geophys. Res., 104, 18815-18840, 1999.

Harwood, R. S. and Pyle, J. A.: 2-dimensional mean circulation model for atmosphere below $80 \mathrm{~km}$, Q. J. Roy. Meteor. Soc., 101(430), 723-747, 1975.

Heath, D. F. and Park, H.: The solar backscatter ultraviolet (SBUV) and total ozone mapping spectrometer (TOMS) experiment, The Nimbus 7 Users' Guide, edited by: C. R. Madrid, Management and Technical Services Company, Beltsville, MD, The Landsat/Nimbus Project, NASA/GSFC, p. 175, 1978.

Houghton, J. T., Ding, Y., Griggs, D. J., et al.: Climate Change 2001: Working Group I: The Scientific Basis, Cambridge University Press, http://www.ipcc.ch/ipccreports/tar/wg1/147.htm, 2001. 
IPCC: Climate Change 2007: The Physical Science Basis, Contribution of Working Group I to the Fourth Assessment Report of the Intergovernmental Panel on Climate Change, edited by: Solomon, S., Qin, D., Manning, M., Chen, Z., Marquis, M., Averyt, K. B., Tignor, M., and Miller, H. L., Cambridge University Press, Cambridge, United Kingdom and New York, NY, USA, 996 pp., 2007

Jöckel, P., Tost, H., Pozzer, A., Brühl, C., Buchholz, J., Ganzeveld, L., Hoor, P., Kerkweg, A., Lawrence, M. G., Sander, R., Steil, B., Stiller, G., Tanarhte, M., Taraborrelli, D., van Aardenne, J., and Lelieveld, J.: The atmospheric chemistry general circulation model ECHAM5/MESSy1: consistent simulation of ozone from the surface to the mesosphere, Atmos. Chem. Phys., 6, 50675104, 2006,

http://www.atmos-chem-phys.net/6/5067/2006/.

Kumer, J. B., Mergenthaler, J. L., and Roche, A. E.: CLAES CH 4 , $\mathrm{N}_{2} \mathrm{O}$ and $\mathrm{CCl}_{2} \mathrm{~F}_{2}$ (F12) global data, Geophys. Res. Lett., 20(12), 1239-1242, 1993.

Lary, D. and Pyle, J. A.: Diffuse-radiation, twilight, and photochemistry.1., J. Atmos. Chem., 13(4), 393-406, 1991.

Law, K. S., Plantevin, P. H., Shallcross, D. E., Rogers, H. L., Pyle, J. A., Grouhel, C., Thouret, V., and Marenco, A.: Evaluation of modeled $\mathrm{O}_{3}$ using Measurement of Ozone by Airbis In-Service Aircraft (MOZAIC) data, J. Geophys. Res., 103(D19), 2572125737, 1998.

Lock, A P.,A. R. Brown, M. R. Bush, G. M. Martin, and R. N. B. Smith: A new boundary layer mixing scheme. Part I: Scheme description and single-column model tests, Mon. Weather Rev., 128, 3187-3199, 2000.

Morgenstern, O., Braesicke, P., Hurwitz, M. M., O'Connor, F. M., Bushell, A. C., Johnson, C. E., and Pyle, J. A.: The World Avoided by the Montreal Protocol, Geophys. Res. Lett., 35, L16811, doi:10.1029/2008GL034590, 2008.

Naujokat, B.: An update of the observed quasi-biennial oscillation of the stratospheric winds over the tropics, J. Atmos. Sci., 43, 1873-1877, 1986.

Neu, J. L., Prather, M. J., and Penner, J. E.: Global atmospheric chemistry: Integrating over fractional cloud cover, J. Geophys. Res., 112, D11306, doi:10.1029/2006JD008007, 2007.

Price, C. and Rind, D.: A simple lightning parameterization for calculating global lightning distributions, J. Geophys. Res., 97(D9), 9919-9933, 1992.

Priestley, A.: A quasi-conservative version of the semi-Lagrangian advection scheme, Mon. Weather Rev., 121(2), 621-629, 1993.

Randel, W. J., Wu, F., and Stolarski, R.: Changes in column ozone correlated with the stratospheric EP flux, J. Meteorol. Soc. Japan, 80(4B), 849-862,2002.

Rayner, N. A., Parker, D. E., Horton, E. B., Folland, C. K., Alexander, L. V., Rowell, D. P., Kent, E. C., and Kaplan, A.: Global analyses of sea surface temperature, sea ice, and night marine air temperature since the late nineteenth century, J. Geophys. Res., 108(D14), 4407, 10.1029/2002JD002670, 2003.

Russell, J. M. III, Gordley, L. L., Park, J. H., Drayson, S. R., Hesketh, W. D., Cicerone, R. J., Tuck, A. F., Frederick, J. E., Harries, J. E., and Crutzen, P. J.: The Halogen Occultation Experiment, J. Geophys. Res., 98(D6), 10777-10797, 1993.
Sander, S. P., Friedl, R. R., Golden, D. M., et al.: Chemical kinetics and photochemical data for use in atmospheric studies, JPL Publications 02-25, 2003.

Scaife, A. A., Butchart, N., Warner, C. D., and Swinbank, R.: Impact of a spectral gravity wave parametrization on the stratosphere in the Met Office Unified Model, J. Atmos. Sci., 59, 1473-1489, 2002.

Schultz, M., Rast, S., van het Bolscher, M., et al.: Emission data sets and methodologies fir estimating emissions, Work package 1, Deilverable D1-6, Reanalysis of tropospheric chemical composition over the past 40 years, A long-term global modeling study of tropospheric chemistry funded under the 5th EU framework programme, http://retro.enes.org/reports/D1-6_final.pdf, 2007.

SPARC: SPARC assessment of stratospheric aerosol properties (ASAP), Tech. Rep. WMO-TD No. 1295, WCRP Series Report No. 124, SPARC Report No. 4, Berrieres le Buisson, Cedex, 2006.

Spracklen, D. V., Pringle, K. J., Carslaw, K. S., Mann, G. W., Manktelow, P., and Heintzenberg, J.: Evaluation of a global aerosol microphysics model against size-resolved particle statistics in the marine atmosphere, Atmos. Chem. Phys., 7, 2073-2090, 2007, http://www.atmos-chem-phys.net/7/2073/2007/.

Stolarski, R. S. and Frith, S. M.: Search for evidence of trend slowdown in the long-term TOMS/SBUV total ozone data record: the importance of instrument drift uncertainty, Atmos. Chem. Phys., 6, 4057-4065, 2006, http://www.atmos-chem-phys.net/6/4057/2006/.

Telford, P. J., Braesicke, P., Morgenstern, O., and Pyle, J. A.: Technical Note: Description and assessment of a nudged version of the new dynamics Unified Model, Atmos. Chem. Phys., 8, 17011712, 2008, http://www.atmos-chem-phys.net/8/1701/2008/.

Thompson, D. W. J., and S. Solomon, Interpretation of recent Southern Hemisphere climate change, Science, 296, 5569, 895899, 2002.

Untch, A., Simmons, A., et al.: Increased stratospheric resolution in the ECMWF forecasting system, ECMWF Newsletter, 82, 2-8, 1998.

Uppala, S. M., Kallberg, P. W., Simmons, A. J., et al.: The ERA-40 re-analysis, Q. J. Roy. Meteor. Soc., 131, 2961-3012, doi:10.1256/qj.04.176, 2005.

Waugh, D., Atmospheric dynamics: The age of stratospheric air, Nature Geosci., 2, 14-16, doi:10.1038/ngeo397, 2009.

Webster, S., Brown, A. R., Cameron, D. R., and Jones, C. P.: Improvements to the representation of orography in the Met Office Unified Model, Q. J. Roy. Meteor. Soc., 129, 1989-2010, 2003.

Wild, O. and Prather, M. J.: Excitation of the primary tropospheric chemical mode in a three-dimensional model, J. Geophys. Res., 105(D20), 24647-24660, 2000.

WMO (World Meteorological Organization): Scientific Assessment of Ozone Depletion: 2006, Global Ozone Research and Monitoring Project - Report No. 50, 572 pp., Geneva, Switzerland, 2007.

Zeng, G. and Pyle, J. A.: Changes in tropospheric ozone between 2000 and 2100 modeled in a chemistry-climate model, Geophys. Res. Lett., 30(7), 1392, doi:10.1029/2002GL016708, 2003. 